\title{
Mental Incapacity and Liability Insurance Exclusionary Clauses: The Effect of Insanity upon Intent
}

\author{
Catherine A. Salton $\uparrow$
}

Insurance coverage is usually denied where an individual intentionally causes damage to persons or property. The analysis becomes more complicated, however, where the mental capacity of the insured is in question. Courts have used a number of tests to examine the mental state of an insured in order to determine whether she could form the requisite intent. This Comment begins by examining the judicial confusion and inconsistency in applying these tests. The author argues that the existing tests are unsatisfactory, both in their formulation and in their application. The author proposes a new test for ascertaining mental capacity of an insured, one that will provide consistency, avoid confusion, and accord with the public policy of insurance.

When an imdividual who has purchased a standard liability or homeowner's insurance policy purposefully causes property damage or personal mjury, an exclusionary provision within his policy generally denies coverage for the consequences of his act on the grounds that the harm was caused intentionally. When the mental capacity of the insured is in question, both the determination of intent and the application of the intentional act exclusionary clause are difficult. Courts have responded to this problem by developing various insanity "tests" to discern whether an insured was so mentally impaired that his acts could not be viewed as "intentional."

However, the courts are in conflict on the proper criteria to use to define insamity within each test. Courts liave developed two basic lines of authority on the issue. Generally, the first view holds that if an injury results from an insane act, the intentional injury clause is moperative and the insurer is liable. The other view holds that an injury inflicted by an insane person nuay be "intentional" where the actor understands the physical nature and consequences of the act, even thougl he is incapable

$\dagger$ B.A. 1985, University of Rochester; J.D. 1990, Boalt Hall School of Law, University of California, Berkeley. The author would hike to thank Professor Justin Sweet and Michael Page for their assistance. 
of distinguishing right from wrong. While these are the two basic positions courts have adopted, courts do not hesitate to alter their language from case to case. As a result, there is considerable confusion and inconsistency in this area of the law. This Comment will argue that the current tests are unsatisfactory, and that there is a need for a single test to determine mental incapacity for the purposes of intentional act exclusionary clauses. This Comment will offer a workable, alternative test for the courts.

Part I of the Comment will discuss the purposes of intentional act exclusionary clauses in insurance policies, the relevant doctrines and public policies involved in insurance law, and the determination of intent im cases where insanity is not at issue. Part II will explain the foundations of the treatment of insanity in insurance cases through an examination of the different approaches taken under tort and criminal law. Part III will identify and compare the various tests the courts have applied to determine whether an act performed by an insured whose mental capacity is in question was intentional for the purposes of insurance coverage. Part III will also argue that the various tests used by the courts in this situation are substantially flawed. Finally, the Comment will propose an alternative test desigued to avoid the problems of the existing tests, provide consistency of results, and remain in accordance with the fundamental public policies behind insurance law.

I

\section{Intentional Act Exclusionary Clauses: Policy BACKGROUND AND APPLICATION}

\section{A. Policy Background}

Liability insurance policies are designed to furnish coverage for legal hability incurred by an insured as a result of unintentional and unexpected property damage and/or personal injury. ${ }^{1}$ Actual policy language implements this design in two ways: (1) it restricts coverage to injury or dan1age resulting from an "accident"; and (2) it excludes from coverage injuries and daniage that are "intended or expected" by an insured. ${ }^{2}$ The

1. Rynearson, Exclusion of Expected or Intended Personal Injury or Property Damage Under the Occurrence Definition of the Standard General Liability Policy, 19 FORUM 513, 513 (1984).

2. DiMugno, Insurance Coverage for Intentional and Criminal Acts: An Overview, 1 INS. L. BRIEFINGS 151, 152 (1988). It is important to note that the standard policy language for liability insurance has undergone substantial change over the last twenty-five years. Prior to 1966, liability policies generally stated that damage or injury would be covered by the policy only if it was "caused by an accident which occurs during the policy period." Id. at 153 . Any duty of the insurer to defend or indemnify the insured was restricted by this "accident" requirement. Note, Intentional Injury Exclusion Clauses-What Is Insurance Intent?, 32 WAYNE L. REv. 1523, 1524 (1986) (authored by Kristin Wilcox). Due to the difficulties encountered by the courts in construing the word "accident"-including conflicting opimions on whether the term was to be understood from the 
typical general business liability policy, which covers only liability incurred in the course of doing business, combines these two conditions within a single coverage clause. ${ }^{3}$ The typical individual policy, sucl as a hoineowner's or renter's policy, contains personal liability coverage for liability incurred by an individual personally. ${ }^{4}$ Unlike business liability policies, individual policies generally do not exclude intentional or expected injuries within the coverage clause. ${ }^{5}$ Instead, most of these policies liave a separate clause that excludes coverage for injuries or damage intentionally caused by the insured. ${ }^{6}$ This separate provision is generally called an intentional injury exclusion clause. ${ }^{7}$

Recognizing that the fundamental purpose of insurance is to protect against accidental events, ${ }^{8}$ courts have generally accepted intentional injury exclusion clauses as valid limitations on liability. ${ }^{9}$ The reasons for this acceptance are manifold, ranging from simple economics to theories of "moral hazard" and deterrence. One important reason is that insurers calculate the premiums for policies based on the probabilities of accidental losses. If the policy covered intentional losses, the insured would be in control of the risk, thereby denying the insurer the ability to fix rates fairly and efficiently. ${ }^{10}$ A closely related reason is that of "moral hazard," whicl1 assumes that an individual who has insurance coverage for his intentional wrongdoing will be more likely to perform sucl acts. ${ }^{11} \mathrm{~A}$

viewpoint of the insured or the victim-the National Bureau of Casualty Underwriters and the Mutual Insurance Rating Bureau rewrote the standard policy language in 1966. Id. at 1524. This 1966 revision provided coverage for "damages . . caused by an occurrence," and defined occurrence as "an accident ... which results, during the policy period, in bodily injury or property damage neither expected nor intended from the standpoint of the insured." Id. at 1524-25; DiMugno, supra, at 153. The revision established that "accident" was defined from the standpoint of the insured, not the victim. This position was favorable to insurers, since it denied coverage to insureds who committed intentional torts. Note, supra, at 1524-25.

3. DiMugno, supra note 2, at 153. The coverage clause is the section of the policy that actually grants coverage. The 1966 revised standard policy language, see supra note 2, is an example of a coverage clause that excludes intentional injury or damage.

4. DiMugno, supra note 2 , at 153.

5. Id.

6. Id. at 154 .

7. Annotation, Liability Insurance: Intoxication or Other Mental Incapacity Avoiding Application of Clause in Liability Policy Specifically Exempting Coverage of Injury or Damage Caused Intentionally By or At Direction of Insured, 33 A.L.R. 4th 983, 986 (1984).

8. DiMugno, supra notc 2, at 152.

9. See, e.g., George v. Stone, 260 So. 2d 259, 261 (Fla. Dist. Ct. App. 1972); Butler v. Peninsular Life Ins. Co., 115 So. 2d 608, 608-09 (Fla. Dist. Ct. App. 1959); Ruvolo v. American Casualty Co., 39 N.J. 490, 496, 189 A.2d 204, 207 (1963).

10. J. Appleman \& J. Appleman, Insurance Law and Practice $\$ 4492.01$, at 21 (W. Berdal ed. 1979). One could hardly expect an insurance company to calculate effectively the probability of intentional losses.

11. See Forster \& Steinmüller, An Alternative View of Moral Hazard, 45 J. RISK \& INS. 531 (1978) (a moral hazard in insurance implies that, under the policy, the class of insureds will mcur higher losses than it would if it were not insured); see also W. Young \& E. Holmes, INSURANCE CASES AND MATERIALS ON THE LAW OF INSURANCE 137 (2d ed. 1985) (moral hazard refers to the 
third reason, which ignores the effect on insurers, is based upon the wellestablished public policy prohibiting insureds from indemnification for injury or damage caused by their own intentional wrongful acts. ${ }^{12}$ This pohicy justification often supports judicial endorsement of intentional act exclusion clauses. In fact, this public policy has gone beyond judicial apphication to statutory codification in two states. ${ }^{13}$

Two rationales support the prohibition against indemnifying an insured for her intentional wrongful acts. First, and perhaps clearest, is a general, societal interest in deterring wrongful conduct on the part of the insured. ${ }^{14}$ As one comnientator has noted, "a tortfeasor should not ... be encouraged to commit intentional torts knowing that [her] mischief will be underwritten by an insurer."15 The second, related rationale is that of punishing the intentional tortfeasor by forcing her to bear the financial consequences of her acts. ${ }^{16}$

While policies favoring denial of coverage for intentional acts may seem fair, they conflict with the policy favoring the compensation of innocent victims. ${ }^{17}$ Often, the person who inflicts damage or injury is not financially capable of compensating the victim out of pocket; therefore, the victim's only opportunity for payment may depend on access to the

"comparative degree of control as between contracting parties, that can be exercised over the balance of advantages conferred by the contract").

12. Note, supra note 2, at 1528; Case Comment, Liability Insurance for Intentional TortsSubrogation of the Insurer to the Victim's Rights Against the Insured: Ambassador Ins. Co. v. Montes, 32 RutGers L. REv. 155, 157 (1979) (authored by H. Karen Cuttler). For examples of cases applying this principle, see Ruvolo v. American Casualty Co., 39 N.J. 490, 496, 189 A.2d 204, 207 (1963); Malanga v. Manufacturers Casualty Insurance Co., 28 N.J. 220, 225, 146 A.2d 105, 108 (1958); Morgan v. Greater New York Taxpayers Mutual Insurance Association, 305 N.Y. 243, 248, 112 N.E.2d 273, 275 (1953).

13. See CAL. INS. CODE $\S 533$ (West 1990) ("An insurer is not liable for a loss caused by the wilful act of the insured; but he is not exonerated by the negligence of the insured, or of the insured's agents or others."); N.D. CENT. CODE § 26.1-32-04 (1989). This longstanding public policy is also reflected in the California Civil Code: "All contracts which have for their object, directly or indirectly, to exempt anyone from responsibility for his own fraud, or wilful injury to the person or property of another, or violation of law, whether wilful or negligent, are against the policy of the law." CAL. Crv. CodE $\S 1668$ (West 1990).

14. See Case Comment, supra note 12, at 157-58; see also Globe Am. Casualty Co. v. Lyons, 131 Ariz. 337, 339-40, 641 P.2d 251, 253-54 (Ct. App. 1981); Home Ins. Co. v. Neilsen, 165 Ind. App. 445, 450-51, 332 N.E.2d 240, 244 (1975); Burd v. Sussex Mut. Ins. Co., 56 N.J. 383, 398, 267 A.2d 7, 15 (1970).

15. Note, Insanity: How Does It Affect Liability Insurance Exclusions for Intentional Torts? Arizona Adopts the Ruvolo Test, 24 ARIz. L. REv. 1046, 1054 (1982) (authored by Eric J. Olsson).

16. Case Comment, supra note 12, at 157-58; see also Congregation of Rodef Sholom v. American Motorists Ins. Co., 91 Cal. App. 3d 690, 697, 154 Cal. Rptr. 348, 352 (1979) ("The exclusion of intentional imjury steins from a behef that an individual should not be exempt froin the financial consequences of his own intentional injury to another."); Isenhart v. General Casualty Co. of Am., 233 Or. 49, 53, 377 P.2d 26, 28 (1962).

17. See, eg., Note, supra note 15, at 1053; Note, supra note 2, at 1528; see also Rodef Sholom, $91 \mathrm{Cal}$. App. 3d at 697, 154 Cal. Rptr. at 352; Burd v. Sussex Mut. Ins. Co., 56 N.J. 383, 398-99, 267 A.2d 7, 15 (1970). 
wrongdoer's insurance coverage. ${ }^{18}$

Various principles of contract interpretation work in concert with this compensation policy, and courts often rely upon these principles to support compensation of the injured party. In accordance with the contract doctrine of contra proferentum, ${ }^{19}$ courts have taken the position that anbiguous exclusionary provisions are to be strictly construed against the insurer. ${ }^{20}$ Under this reasoning, the insured is entitled to protection to the fullest extent that any reasonable interpretation of the exclusionary clause will permit, especially when the conduct insured agamst involves possible injury or damage to innocent third parties. ${ }^{21}$

The contra proferentum doctrine has been applied with particular force to insurance policies. As one court pointed out, insurance contracts are "drawn for the company by inen learned in the law of insurance";22 it is unlikely that the hapless purchaser of the policy will be equally educated. Also, insurance policies, especially homeowners' and renters' pohicies, are standardized, with very hittle opportunity for a typical insured to negotiate the terms. ${ }^{23}$ In otler words, insurance policies contain all the elements of adhesion contracts.

Other interpretation doctrines that have been used to restrict the scope of exclusionary clauses include the doctrine of plain meaning, by which courts construe policy language according to the understanding of the average person who buys the policy, ${ }^{24}$ and the related doctrine of reasonable expectations, which protects the reasonable expectations of a policy purchaser even where there is no ambiguity in the policy language. ${ }^{25}$

18. See Note, supra note 2 , at 1528 . This commentator also notes that courts may be more comfortable with finding coverage and thus placing the burden of the loss on the insurer, rather than denying coverage and shifting the loss to the insured or to the victim. Id.

19. This doctrine provides that where a court must choose among the reasonable meanings of terms in a proinise or agreement, the preferred meaning is the one that operates against the party who supplied the terms. RESTATEMENT (SECOND) OF CONTRACTs § 206 (1981). It is important to note, however, that ambiguity is necessary before the doctrine of contra proferentum apphes. If the language of the contract is clear and unambiguous, a court must give effect to that language. See $\mathrm{W}$. YOUNG \& E. HOLMES, supra note 11, at 55-56, and cases collected therein.

20. See, e.g., Globe Am. Casualty Co. v. Lyons, 131 Ariz. 337, 339, 641 P.2d 251, 253 (Ct. App. 1981); Rodef Sholom, 91 Cal. App. 3d at 697, 154 Cal. Rptr. at 352; George v. Stone, 260 So. 2d 259, 262 (Fla. Dist. Ct. App. 1972); Rajspic v. Nationwide Mut. Ins. Co., 110 Idaho 729, 732, 718 P.2d 1167, 1170 (1986); Ruvolo v. American Casualty Co., 39 N.J. 490, 498, 189 A.2d 204, 208 (1963).

21. See, e.g., Lyons, 131 Ariz. at 340, 641 P.2d at 254 (quoting Ruvolo, 39 N.J. at 498, 189 A.2d at 208-09) ("[Justice demands that particular einphasis be laid on that doctrine where the conduct insured against involves possible injury or damage to inembers of the public."); Rodef Sholom, 91 Cal. App. 3d at 697, 154 Cal. Rptr. at 352.

22. Ruvolo, 39 N.J. at 498,189 A.2d at 208.

23. Note, supra note 2, at 1529.

24. See W. Young \& E. HolmEs, supra note 11, at 55-56, and cases collected therein.

25. See Keeton, Insurance Law Rights at Variance With Policy Provisions, 83 HaRv. L. Rev. 
Courts liave liad to keep these coinpeting sets of policies and doctrines in mind as they liave atteinpted to interpret the ineaning of "intent" for the purposes of applying intentional injury exclusion clauses. The next Section provides a background of the courts' approaclies to determining intent when nental capacity is not at issue.

\section{B. Application of the Policy-Determining Intent When the Insured Is Not Insane}

In cases where an insured is not insane, courts have generally taken one of three positions on the ineaning of "intent" for the purpose of interpreting insurance exclusionary clauses. ${ }^{26}$ The nuajority viewpoint interprets "intent" as requiring that the insured both intended to perform the act that caused the liarmful result and intended that some injury or damage occur froin that act. ${ }^{27}$ This viewpoint lias been called thc subjective intent standard, and as of 1986, approximately twenty-eight states had apphed this test. ${ }^{28}$ As an alternative to the requirenent that the insured actually intended to cause harm, soine courts using the subjective intent standard have used a related "inferred intent" standard. Under this standard, even tlough the insurer may not be able to prove that the insured intended some injury or damage to occur, courts will infer that intent when the insured's intentional act was of sucli a nature that liarm was substantially certain to result. ${ }^{29}$

A second position, which may be called tlie "specific subjective intent" standard, is closely related to the first formulation. This standard also requires that the insured intended to perforn the act. However, instead of demanding that the insured intended some general injury, the specific subjective intent formulation requires that the insured intended to inflict the precise injury or damage that in fact resulted. ${ }^{30}$ This con-

961, 966-68 (1970). Keeton writes, "The objectively reasonable expectations of applicants and intended beneficiaries regarding the terms of insurance contracts will be honored even though painstaking study of the policy provisions would have negated those expectations." Id. at 967. For a thorough discussion of Keeton's views and the doctrine of reasonable expectations, see Rahdert, Reasonable Expectations Reconsidered, 18 CoNN. L. REv. 323 (1986). Although at first glance it seems unlikely, the doctrine has been used as a sword to deny coverage, see, e.g., American Family Mut. Ins. Co. v. Peterson, 405 N.W.2d 418, 419 (Minn. 1987) (holding that it would not have been reasonable for the insured to expect his policy coverage to include acts committcd while voluntarily intoxicated), as well as a shield to preserve it, see, e.g., Mara v. Fire Ins. Exch., 222 Cal. App. 3d 590, 271 Cal. Rptr. 620 (1990).

26. See, e.g., Farmers Ins. Group v. Sessions, 100 Idaho 914, 916-17, 607 P.2d 422, 424-25 (1980); see also R. JERRY, UNDERSTANDING INSURANCE LAW 306 (1987).

27. See generally Note, The Expansion of Insurance Coverage to Include the Intentional Tortfeasor, 23 LOY. L. REv. 122, 128 (1977) (authored by Judith A. Warshawsky).

28. See Note, supra note 2 , at 1531 n.47.

29. See id. at 1532 .

30. See, e.g., Rajspic v. Nationwide Mut. Ins. Co., 110 Idaho 729, 733, 718 P.2d 1167, 1171 (1986); see also R. JERRY, supra note 26, at 306. 
struction provides the widest coverage for an insured, because the exclusionary clause does not apply if the consequences of an act are not exactly what the insured had in mind. ${ }^{31}$

The third position used by some courts is the objective intent standard. ${ }^{32}$ Under this rule, courts deny coverage when they find that a reasonable person would have foreseen harm from the given act. ${ }^{33}$ Courts presume that the insured intended the natural and probable consequences of his acts, ${ }^{34}$ thus judicially injecting the traditional tort doctrine of foreseeability into insurance imtent hitigation. ${ }^{35}$ Naturally this position results in fewer decisions awarding coverage.

Although these three views appear relatively easily separable, in practice they are not. For example, in one case the Arizona court described its test as follows: "[I]f the injury results from the natural and probable consequences of the intentional act, the subjective intent of the actor is simply immaterial - the exclusion apphies." ${ }^{36}$ This test has been described as "subjective" by one cominentator ${ }^{37}$ and "objective" by another. ${ }^{38}$ One commentator suggests that many courts have confused their terminology in attempting to apply a given test. ${ }^{39}$

Thus, even when the capacity of the insured is not at issue, the application of intentional act exclusion clauses has proven difficult. When, however, a question arises as to the insured's capacity, the apphcation becomes even -more difficult because the above-described tests have been largely abandoned. As this Comment will show, the overwhelming majority of reported opinions do not use these tests as described when dealing with an imsured who is insane. ${ }^{40}$

In the case of either the subjective intent standard ${ }^{41}$ or the specific subjective intent standard, ${ }^{42}$ the reason for this abandonment is clear. The subjective intent to perform a harmful act to cause some injury

31. See Rajspic, 110 Idaho at 733, 718 P.2d at 1171; R. JERRY, supra note 26, at 306.

32. See Note, supra note 2, at 1534. As of 1986, the objective intent standard had been applied in approximately ten states. See id. at 1534 n.65.

33. Id. at 1530 .

34. Id. at 1534 .

35. See id. at 1534 \& n.66; see also R. JERRY, supra note 26, at 306.

36. Steinmetz v. National Am. Ins. Co., 121 Ariz. 268, 271, 589 P.2d 911, 914 (Ct. App. 1978).

37. See Note, supra note 2, at 1531 n.47.

38. See Note, supra note 15, at 1047 (1982). This confusion may lave been caused by the Steinmetz court's usage of an inferred intent standard, which the author of Note, supra note 2, perceives as "objective," but which the author of Note, supra note 15, perceives as an alternative eleinent of the "subjective" test.

39. See Note, supra note 2, at 1535-39 (discussing the confusion in terminology evidenced in different opinions in the Illinois courts and the problems that confusion creates in predicting the outcoine of a given case).

40. See infra text accoinpanying notes 130-234.

41. See supra text accompanying notes 27-29.

42. See supra text accompanying notes 30-31. 
presumes the insured's capacity to form an intention; the focus is on whether only the act, or whether the act and an injury (generally or of a specific type) were intended. In a case where the insured inay have been insane or intoxicated, the focus of the court's attention must shift to the actual condition of the insured to determine whether he was mentally capable of formulating an intent at all at the time of the wrongful act.

The rationale for a separate test for insane insureds is less clear when the standard used is that of objective intent, or the inferred intent standard occasionally used in subjective intent jurisdictions. ${ }^{43}$ Under either of these standards, the actual intent of the insured to cause harm is not relevant to a finding that the exclusion clause apphes, because the courts will presume that the insured intended the natural and probable consequences of his acts. If the actual intent of the insured is immaterial under these rules, ${ }^{44}$ a inental illness of the insured which may have negated the capacity to form the intent should also be immaterial.

The specialized tests that courts apply to insane insureds bear little resemblance to those applied to other insureds. In order to understand the foundation for these tests, it is useful to examine the treatment of insanity under tort and criminal law.

II

VIEWS OF INSANITY UNDER TORT AND CRIMINAL LAW

\section{A. The Treatment of the Insane Under Tort Law}

As a general rule in tort law, insane or mentally retarded individuals are hable for the torts they commit. ${ }^{45}$ The vast majority of courts have

43. See supra text accompanying notes 29-35.

44. See Note, supra note 2, at 1530-31 ("It is irrelevant that the insured did not actually intend harm, for it is assumed she intended the natural and probable consequences of her acts.").

45. See W. Prosser, D. Dobbs, R. Keeton \& D. OWen, Prosser and Keeton on the LAW OF TorTs $\S 135$, at 1072 (5th ed. 1984) [hereinafter Prosser \& KeEToN]; Curran, Tort Liability of the Mentally Ill and Mentally Deficient, 21 OHо ST. L.J. 52, 52 (1960); Ellis, Tort Responsibility of Mentally Disabled Persons, 1981 AM. B. FouND. REs. J. 1079, 1081. 
adopted this position; ${ }^{46}$ five states have statutorily codified it ${ }^{47}$ and it is the official view of the Restatement (Second) of Torts. ${ }^{48}$

This general rule is applied to both neghigent and intentional torts. In the area of neghigent torts, a inentally disturbed person is expected to comply with the objective "reasonable man" standard, a standard that presupposes both reasonableness and emotional stability. ${ }^{49}$ The rule holding insane individuals responsible is almost invariably applied witl respect to intentional torts as well, ${ }^{50}$ although there is some authority lolding that an insane person may not have the mental capacity to form the specific intent that is an essential element of certain imtentional torts, ${ }^{51}$ such as malicious prosecution, alienation of affection, misrepresentation, and defamation. ${ }^{52}$ When the intent required to create liability for a given tort is less sophisticated, insane persons will be held liable. ${ }^{53}$ Furthermore, a najority of courts hold insane individuals hable for their intentional killings in wrongful death actions. ${ }^{54}$

The principles behind this nearly monolithic viewpoint on the tort responsibility of insane persons are botli long-establislied ${ }^{55}$ and longcontested.56 Justifications of the general rule have included the following:

46. Louisiana appears to be the only state whose courts impose no liability on insane tortfeasors. See Yancey v. Maestri, 155 So. 509, 515 (La. Ct. App. 1934) (adopting the "wellrecognized rule or precept of civil law, that an insane person is not liable in damages for his tortious acts"). However, one subsequent Louisiana decision may have cast some doubt on the continuing validity of Yancey. In Von Dameck v. St. Paul Fire \& Marine Insurance Co., 361 So. 2d 283, 289 (La. Ct. App.), cert. denied, 362 So. $2 d 794$ (La.), cert. denied, 362 So.2d 802 (La. 1978), the court specifizally refused to comment on the continuing validity of the case. One court has taken the position that insanity may be a defense to a negligence cause of action where the actor is suddenly, without forewarning, overcome by a mental disability or disorder that prevents him from conforming to the "reasonable inan" standard. Breunig v. American Family Ins. Co., 45 Wis. 2d $536,542,173$ N.W.2d 619, 623 (1970). However, other courts have long rejected this "sudden insanity" defense. See, e.g., Kuhn v. Zabotsky, 9 Ohio St. 2d 129, 133, 224 N.E.2d 137, 141 (1967); Sforza v. Green Bus Lines, Inc., 150 Misc. 180, 181-82, 268 N.Y.S. 446, 447-48 (N.Y.C. Muni. Ct. 1934).

47. See CaL. Crv. Code $\S 41$ (West 1990); Mont. Code ANN. § 27-1-711 (1989); N.D. CENT. CODE § 14-10-03 (1981); OKLA. STAT. ANN. tit. 15, §§ 25, 26 (West 1972); S.D. Codified LAWS ANN. \& 27A-2-4 (1976).

48. See RESTATEMENT (SECOND) OF TORTS § 283B (1965).

49. See Coleman, Mental Abnormality, Personal Responsibility and Tort Liability, in MENTAL Illness: LAW AND PuBlic Policy 112 (B. Brody \& H. Engelhardt eds. 1980).

50. See Ellis, supra note 45 , at 1081 .

51. See Prosser \& KeEton, supra note $45, \S 135$, at 1074.

52. See Ellis, supra note 45 , at 1081 n.12.

53. Curran, supra note 45 , at 54-55 (noting that insane persons have been held hable for the intentional torts of trespass to land, conversion, and assault and battery).

54. See id. at 56-57.

55. See id. at $54 \&$ n.12 (noting that this policy was already established in cases dating back to 1845).

56. Prosser \& KeETON, supra note 45, at 1073. For a thorough discussion of the weaknesses of traditional tort rationales about the inentally disabled, see Ellis, supra note 45, at 1084-1109. 
1. The fairness of holding that "where one of two innocent persons must suffer a loss, it should be borne by the one who occasioned it"; 57

2. The encouragement of custodians or caretakers to be vigilant over the care of insane persons; ;8

3. The prevention of dishonest defendants from capitalizing on the difficulty of identifying actual inental illness by successfully feigning insanity to avoid hability for harmful acts; ${ }^{59}$ and

4. The coinplications and difficulties of introducing insanity defenses as used in the criminal law into tort doctrine. ${ }^{60}$

Insurance law generally does not follow the tort position because of the public policies specific to insurance law. ${ }^{61}$ However, these policies are not totally unrelated in spirit to some of the tort justifications. For instance, the insurance approach, which stresses the policy interest in awarding coinpensation to victims of attacks by insane persons, ${ }^{62}$ is in accord with the tort law emphasis on the coinpensation of victims (nuinber 1 above). As another example, the deterrence rationale underlying exclusionary clauses themselves ${ }^{63}$ is ill-served by denying coverage to insane insureds, because an individual who lacks the mental capacity to conforin his behavior to acceptable standards will not be deterred by the nonexistence of insurance coverage for the harm he inflicts. ${ }^{64}$ This reasoning does not conflict with the "vigilance" rationale often advanced in tort law (number 2 above), because one aspect of a custodian's duty to protect third parties against harm from an insane person could be to obtain insurance against the harmful results of the insane person's acts. Lastly, various doctrines such as plain meaning and contra proferentum $^{65}$ apply in insurance law, since it is based upon the existence of a contract, whereas they do not operate within the tort context. These

57. Ellis, supra note 45, at 1083 (quoting Seals v. Snow, 123 Kan. 88, 90, 254 P. 348, 349 (1927)). Professor Ellis notes that "this reason is frequently cited in both early and recent cases." Id. at 1083 n.21. See, e.g., Kaczer v. Marrero, 324 So. 2d 717, 718 (Fla. Dist. Ct. App. 1976); Williams v. Hays, 143 N.Y. 442, 447, 38 N.E. 449, 450 (1894).

58. Curran, supra note 45 , at 54 ; Ellis, supra note 45 , at 1083.

59. Curran, supra note 45, at 54; Ellis, supra note 45 , at 1084.

60. Prosser \& KeEton, supra note 45, § 135, at 1073; Curran, supra note 45, at 54; Ellis, supra note 45 , at 1084 . As a result of the rejection of insanity as a defense to tort actions, there has been almost no atteinpt to define what is ineant by insanity in tort cases. See Curran, supra note 45 , at 64 .

61. See infra text accompanying notes 62-65.

62. See, e.g., Ruvolo v. American Casualty Co., 39 N.J. 490, 498, 189 A.2d 204, 208-09 (1963); see also Note, supra note 27 , at 142 ("[1]nsurance protects the interests of the injured party as well as those of the insured.").

63. See supra text accompanying note 15.

64. See, e.g., Congregation of Rodef Sholom v. American Motorists Ins. Co., 91 Cal. App. 3d 690, 697, 154 Cal. Rptr. 348, 352 (1979); Rajspic v. Nationwide Mut. Ins. Co., 110 Idaho 729, 732, 718 P.2d 1167, 1170 (1986).

65. See supra text accoinpanying notes 19-25. 
contract doctrines also apply, as several courts have pointed out, to ensure that the purpose of insurance not be defeated. ${ }^{66}$ After all, one of the purposes of obtaining insurance is to provide coverage for the injuries for which the insured is hable.

Perhaps these policies unique to insurance law have encouraged courts to reject tlie strict responsibility position that tort law takes toward the insane. In rejecting the tort position, the courts einbrace an approach very similar to that taken in criminal law: they accept the concept of an insane person's nonresponsibility for his act. Courts in insurance hitigation have ignored the public pohcies rehed upon in tort in order to avoid the complexities of determining insanity (numbers 3 and 4 above). Not unexpectedly, the courts in insurance litigation have adopted many of the concepts, approaches, and even the language used in criminal cases where the defendant is insane. ${ }^{67}$

In order to explore the deep-seated relationship between the treatment of insanity in criminal and insurance litigation, tlie next Section will examine the various approaches criminal law has employed in cases of insanity, and will then describe the history, problems, and strengths of insanity tests that have been apphed in criminal cases.

\section{B. The Treatment of the Insane in Criminal Law}

The criminal law approacli to the problem of the insane wrongdoer differs siguificantly from the tort law approach. For centuries, insanity has been treated as a inoral and legal excuse. ${ }^{68}$ The rationale for this treatment of insanity rests upon the basic foundation of criminal law itself-that individuals are responsible for their actions. Mental illness, as seen in traditional criminal doctrine, functions to limit the extent to which a person can be held responsible for what he does. ${ }^{69}$

Two traditional conceptions of nonresponsibility-nonculpable ignorance and compulsion-underhe this perception of imsanity as an excuse. $^{70}$ The 1955 Tentative Draft of the Model Penal Code gives an example of the nonculpable ignorance condition in an insane person.

66. See, e.g., George v. Stone, 260 So. 2d 259, 262 (Fla. Dist. Ct. App. 1972).

67. See infra text accompanying notes 130-234.

68. Moore, Legal Conceptions of Mental Illness, in Mental Illness: Law ANd Public Policy, supra note 49, at 25, 26-27.

69. See id. at 25. In a similar vein, noted commentator Herbert Fingarette has stated: "[The criminal defense of insanity] expresses, in however awkward and circumscribed a way, the principle that one who has lost his reason may not be criminally condemned, that the criminal law is a law for those who can be held responsible for what they do." H. Fingaretre, The Meaning of CRIMINAL INSANITY 7 (1972). Another commentator frames this conception in the language of free will. "The legal system ... is based on a concept of free choice. To the extent that a defendant is deprived of free choice he is exculpated in the eyes of the law." Tyrell, Insanity: A Crazy Defense, 35 Med. TRIAL TeCh. Q. 48, 53 (1989).

70. See Moore, supra note 68 , at 31 . 
This illustration describes a madman who believes that he is squeezing lemons when he cliokes his wife, or beheves that homicide is the command of God. ${ }^{71}$ The man is nonculpable because lis mental illness caused him to be ignorant that he was squeezing his wife's neck or that the homicide was not actually the command of God. An example of the "coinpulsion" condition is an individual who is aware that lie is injuring his victim, but is unable to desist from the act due to an uncontrollable, irresistible force within himself. ${ }^{72}$

In their formulations of traditional criminal insanity tests, American courts have adopted both of tliese excusing conditions. ${ }^{73}$ An exemplar of a nonculpable ignorance test is the traditional M'Naghten test. ${ }^{\mathbf{7 4}}$ The excuse of compulsion is typified in the irresistible impulse test. ${ }^{75}$ Anotlier formulation, developed by the American Legal Institute in the Model Penal Code, combines the two conditions within one test. ${ }^{76}$ In the history of American criminal insanity tests, only the Durham and New Hampshire tests did not rely upon one or both of the ignorance or compulsion excuses. Under these tests, the very status of being mentally ill, as opposed to its "ignorance" or "coinpulsion" manifestations, is regarded as excusing. ${ }^{77}$

In order to understand more fully the elements of these tests, which are the bases from which courts have derived the insanity tests used in insurance litigation, this Comment will briefly describe the tests theinselves as they have been applied and the criticisins made of each one.

\section{The M'Naghten Test}

The M'Naghten formulation lias historically been the landmark standard for the criminal insanity defense. ${ }^{78}$ It is nained after Daniel

71. Model Penal Code $\$ 4.01$ comment 2 (Tent. Draft No. 4, 1955).

72. The excusing conditions of ignorance and compulsion also apply, in the guise of a mistake of fact or duress, to the noninsane criminal defendant. For example, one who believes he is using harmless food coloring when in fact it is a deadly poison is making a mistake of fact, which excuses him from criminal responsibility. An individual who acts under threats from others, or in a state of severe emotional disturbance caused by the victim's provocation, is acting under duress. This duress is also excusing. Moore, supra note 68 , at 31.

73. Id. at 31 .

74. Id.; see also infra text accompanying notes 78-95.

75. Moore, supra note 68, at 32; see also infra text accompanying notes 96-101.

76. Moore, supra note 68, at 32; see also infra text accompanying notes 102-17.

77. See M. MOORE, LAW AND Psychiatry: Rethinking the Relationship 223 (1984); see also infra text accompanying notes 118-29.

78. Note, Returning to M'Naghten to Avoid Moral Mistakes: One Step Forward, or Two Steps Backward for the Insanity Defense? 30 ARIZ. L. REV. 135, 136 (1988) (authored by Robert F. Schopp). As of the end of 1985, 26 states used either the classic M'Naghten formulation or some minor variant of it. Callahan, Mayer \& Steadman, Insanity Defense Reform in the United StatesPost-Hinckley, 11 Mental \& Physical Disabilities L. Rep. 54, 56 (1987). The federal government has also adopted a variant of the M'Naghten test for use in federal courts, which excuses 
M'Naghten, who in 1843 shot and killed Edward Drummond, secretary

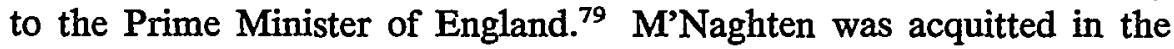
subsequent criminal prosecution, ${ }^{80}$ and the case originated the now classic rule often alternatively termed the "right-wrong test."81 Under this rule, the defendant would be judged criminally insane only if "at the time of the committing of the act, the party accused was labouring under such a defect of reason, from disease of the mind, as not to know the nature and quality of the act he was doing; or, if he did know it, that he did not know he was doing what was wrong." 82

At the time the M'Naghten rule was formulated, many judges and lawyers beheved that the presence of delusions was the only valid indication of inental illness. ${ }^{83}$ M'Naghten combines this conception of inental illness as delusion with the traditional legal excuse of ignorance. ${ }^{84}$ Three conditions are necessary for a finding of insanity under the test: first, a inental disease or defect must be present; second, as a result of this disease or defect, the defendant must suffer from a defect of reason; and third, this defect of reason must manifest itself in a delusional ignorance so that the defendant does not know what he is doing. ${ }^{85}$ This delusional state requireinent is satisfied in two ways under the test: ignorance of the nature and quality of the act, or ignorance that the act was wrong. ${ }^{86}$ The test is disjunctive, for either type of ignorance will exculpate the defendant. However, the "nature and quality" type of ignorance has often been construed narrowly so that only those defendants who are not aware of the physical characteristics of the act and do not recognize that the act is harmful are definitionally insane. ${ }^{87}$ Cases in which the defendant suffers from this type of impairment are rare ${ }^{88}$ so it is most likely that a crimi-

criminal conduct if "the defendant, as a result of a severe mental disease or defect, was unable to appreciate the nature and quality or the wrongfulness of his acts." 18 U.S.C. $§ 17$ (a) (1988).

79. See M'Naghten's Case, 8 Eng. Rep. 718, 719 (H.L. 1843).

80. Id. at 718. A remarkable public uproar resulted from M'Naghten's acquittal, a familiar phenomenon even in recent years. For a recounting of the controversy surrounding the M'Naghten decision at the time, see D. RoBinson, Psychology AND LAW 45-48 (1980).

81. See, e.g., State v. Carlson, 5 Wis. 2d 595, 607, 93 N.W.2d 354, 360 (1958) (referring to the test as both the M'Naghten rule and the right-wrong test).

82. M'Naghten's Case, 8 Eng. Rep. at 722.

83. See M. MOORE, supra note 77 , at 221 .

84. See id.

85. See H. FingaretTE, supra note 69 , at 14.

86. See id. at 142.

87. See Note, supra note 78 , at 136 . One commentator has noted that the "nature and quality" wing of the tests usually has been omitted entirely from the test in Umited States courts. H. FINGARETTE, supra note 69 , at 142.

88. See H. Fingarette \& A. Hasse, Mental Disabilities and Criminal RESPONSIBILITY 29 (1979) ("[ $[\mathrm{t} t$ is usual in insanity trials, for example in the case of homicide, that the defendant cognitively recognizes that he has a gun, that it can kill a person, and that he has no legal justification for doing so, yet shoots the victim."). Professor Moore points out that M'Naghten himself knew that he was shooting a gun in order to kill a human being. Furthermore, M'Naghten 
nal defendant, if adjudged insane, will be found so under the "ignorance that the act is wrong" wing of the test. ${ }^{89}$

The M'Naghten rule has armed judges, lawyers, legal commentators, and laypeople with substantial ammunition to criticize it. ${ }^{90}$ Much of this criticisin revolves around the test's focus on the defendant's cognitive awareness, that is, his knowledge of the nature or inoral status of his acts. ${ }^{91}$ Critics have argned that by limiting legal imsanity to this knowledge eleinent, the test ignores other inportant indicia of inental incapacity such as the "volitional" aspect of personahty, which refers broadly to inotive, desire, intention, will, and purpose, and the "affective" aspect, which refers to feelings, emotions, and inoods.92 A volitional defect is one which prevents an individual from resistimg impulses he knows are wrong. An affective defect is one which prevents an individual froin feeling tliose emotions, such as remorse, whicli would ordinarily prevent him froin acting in harmful ways. Because the M'Naghten test pays no heed to these factors, the test is arguably underinclusive; its effectiveness is limited to a narrow pool of insane people, ${ }^{93}$ and it does not exculpate those people who would appear to a rational person as nientally ill. ${ }^{94}$

Perhaps as a result of these criticisms, the M'Naghten test has in the past been augmented with a volitional eleinent which served as an alternative to the ignorance elements. ${ }^{95}$ This inodified M'Naghten test is conceptually very similar to the next two tests discussed below, the "irresistible impulse" and American Legal Institute ("A.L.I.") tests.

\section{The Irresistible Impulse and A.L.I. Tests}

The irresistible innulse test was formulated in response to the M'Naghten test's failure to provide for vohtional impairments in its definition of exculpatory inental illness. ${ }^{96}$ One commentator points out that although no particular case gives a classic definition of legal insanity as

was aware that homicide was both legally and morally prohibited. Believing he was being

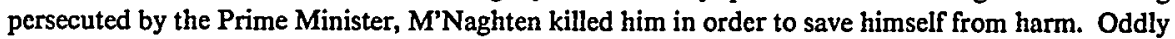
enough, M'Naghten should have failed the insanity test that was named after him. See M. MOoRE, supra note 77, at 223 .

89. Note, supra note 78 , at 136 .

90. See A. Goldstein, The Insanity Defense 46 (1967) (noting that crities describe the test as "a restrictive rule which reflects an outmoded facuity psychology").

91. Id. See also Note, supra note 78, at 138 ("Crities of M'Naghten have argued that the use of "know' limits the defense to a superficial and narrowly cognitive sort of intellectual awareness.").

92. See, e.g., H. FINGARETTE, supra note 69, at 144; Note, supra note 78 , at 136, 138.

93. M. MOORE, supra note 77 , at 219.

94. See H. FINGARETTE, supra note 69 , at 149.

95. See id. at 12. No such augmentation has been taken with respect to an "affective" defect, however. One commentator suggests that this may be due to the dissimilarity between a lack of the usual affective response and the traditional exeuses of ignorance (and, presumabjy, compulsion). Note, supra note 78, at 139 n.34.

96. A. Goldstein, supra note 90, at 68 ; M. Moore, supra note 77 , at 219. 
"irresistible impulse,"97 the case of Parsons $v$. State ${ }^{98}$ provides a representative formulation:

[D]id he know right from wrong, as applied to the particular act im question? . . . If he did have such knowledge, he may nevertheless not be legally responsible if the two following conditions concur: (1) If, by reason of the duress of such mental disease, he had so far lost the power to choose between the right and wrong, and to avoid doing the act in question, as that his free agency was at the time destroyed; (2) and if, at the same time, the alleged crime was so colmected with such mental disease, in the relation of cause and effect, as to have been the product of it solely. 99

Thus, the irresistible impulse test shares with M'Naghten the requirement that a mental disease be present, yet significantly expands the test's exculpatory range. The test encoinpasses an insane person who knows the difference between right and wrong (and presumably was able to identify his act as morally and/or legally wrong at the time of its commission), yet who, as a result of his disease, had lost the ability to control his actions. ${ }^{100}$ Although no state currently follows this insanity test, ${ }^{101}$ the concept of an impairment of volitional capacity was incorporated into the widely used A.L.I. insanity test.

The A.L.I. test was developed in the 1950 s as part of the Model Penal Code ("M.P.C."). ${ }^{102}$ Section 4.01 of the M.P.C. proposes that "[a] person is not responsible for criminal conduct if at the time of such conduct as a result of inental disease or defect he lacks substantial capacity either to appreciate the criminality [wrongfulness] of his conduct or to conform his conduct to the requirements of law."103 In essence, this test combimes the M'Naghten and irresistible impulse tests and nrakes some minor changes in wording. ${ }^{104}$ In the comment to section 4.01 , the Reporter of the Model Penal Code notes that the test includes the vohtional prong because "cognitive factors are not the only ones that preclude inhibition; that even though cognition still obtains, inental disorder may produce a total incapacity for self-control."105 Thus, the basic idea behind the inclusion of the volitional prong in the A.L.I. test is the same as that of the irresistible impulse test. The A.L.I. test differs fron the irresistible impulse test, however, in that it avoids the implication that it

97. M. MOORE, supra note 77 , at 219 .

98. $81 \mathrm{Ala}$. 577, 2 So. 854 (1886).

99. Id. at 596-97, 2 So. $866-67$ (emphasis in original).

100. M. MOORE, supra note 77, at 222.

101. Cf. Callahan, Mayer \& Steadman, supra note 78, at 56 (analyzing insanity tests used in each state).

102. M. MOORE, supra note 77, at 219-20.

103. Model Penal Code $\S 4.01$ (Proposed Official Draft, 1962).

104. M. MOORE, supra note 77, at 222.

105. Model Penal Code $\S 4.01$ comment 2 (Tent. Draft No. 1, 1953). 
is restricted to sudden, spontaneous acts; insane coinpulsion that is accoinpanied by brooding or reflection is also exculpating under the A.L.I. test. ${ }^{106}$

Other changes are worth noting in the A.L.I. test. In contrast to the coinplete impairment of cognitive capacity demanded by the M'Naghten test, or the complete incapacity for self-control required by the irresistible impulse test, the A.L.I. formulation encompasses a lack of "substantial" capacity. ${ }^{107}$ This change was implemented in recognition that most mentally ill people are not completely disoriented, or completely incapable of self-control, ${ }^{108}$ thus providing testifying psychiatrists with a more realistic standard with which to work. ${ }^{109}$ The standard also uses the term "appreciate," mstead of the M'Naghten term "know."110 The cominent to section 4.01 does not discuss the reason or the significance of the change in langnage, but some commentators have suggested that "appreciate" could be intended to broaden the scope of the criterion in order to include affective aspects of personality. ${ }^{111}$ However, proponents of the change froun "know" to "appreciate" have not indicated the specific difference in ineaning between the terms. ${ }^{112}$ One commentator suggests that upon deeper analysis, the terms are virtually interchangeable. ${ }^{113}$

The primary criticisin of tests includimg the volitional prong is that this prong cannot effectively distimguish an irresistible impulse from an impulse not resisted. ${ }^{114}$ The comment to section 4.01 of the Model Penal Code recognizes that the prong inevitably calls for a distinction between

106. See id.

107. See id. $\S 4.01$ comment 4.

108. As pointed out in the comment to $\S 4.01$ :

The schizophremic, for example, is disoriented from reality; the disorientation is extreme; but it is rarely total. Most psychotics will respond to a command of someone in authority within the mental hospital; they thus have some capacity to conform to a norm. But this is very different from the question whether they have the capacity to conform to requirements that are not thus immediately symbolized by an attendant or policeman at

Id. the elbow.

109. See id.

110. Model Penal Code $\S 4.01$ (1) (Proposed Official Draft, 1962).

111. See, e.g., H. FingaRETTE, supra note 69, at 148-51; Note, supra note 78, at 138.

112. See H. FingareTTE, supra note 69, at 152 \& n.33 ("So far as I can see, those who propose replacing 'know' with 'appreciate' or comparable language fail to give any specific and acceptable meaning to the new terms.") (footnote omitted).

113. See M. MOORE, supra note 77 , at 222.

114. See A. Goldstein, supra note 90, at 77 ("[T] he 'control' tests . . . [arc seen as] broaden[ing] the defense far too much, making it available to psychopatlss, to neurotics, perhaps to all who commit crime. This is said to follow from the impossibility of determining which acts were uncontrollable, rather than merely uncontrolled, and the attendant suspicion that the former category does not really exist; from the fact that weaknesses in self-control are to be found in most men; and from the consequent ease of asserting an inability to control one's conduct.") (footnote omitted); see also S. GlueCK, LAW AND Psychiatry: Cold WAR or ENTENTE CoRdiale 50 (1962) ("It is clained to be extremely difficult to prove the actual irresistibleness of a particular impulse.") (footnote omitted); Note, supra note 78, at 140 ("[The ABA and APA] opted for 
incapacity and inere indisposition. But, the problein is not addressed further than a remark that the Institute "believe[s] that the distinction can be inade." 115 Other criticisins of the volitional prong have included concerns about public safety if the prong is included in insanity tests ${ }^{116}$ and confusion in the actual apphication of the test. ${ }^{117}$

\section{The New Hampshire and Durham Tests}

The New Hampshire and Durham tests present a dramatic break from the traditional legal approaches to insanity described above. Instead of attempting to recoinbine the traditional excuses of ignorance and compulsion into a new, "better" formulation, these tests ignore volitional and cognitive criteria and simply mamtain that an accused is not criminally responsible if his uulawful act is a product of a inental disease or defect. ${ }^{118}$ Although both tests were subsequently overruled by the courts that developed them, the tests have had an important impact on the debate over the appropriate standards for determining mental incapacity. ${ }^{119}$

The history of these two tests is too lengthy to recount here, ${ }^{120}$ but both tests are based upon the behef that mental illness is im essence a plrysical disease. ${ }^{121}$ Botli share the assumption that if a criminal act is the result of such an abnormal medical condition, the defendant is ipso facto not responsible for his behavior, regardless of what actual behavioral form his disease may take. The acceptance of the view that mental illness is a scientific concept led to the natural conclusion that the medical professionals involved-that is, psychiatrists-were umiquely qualified to testify to the court on whether or not a defendant had such a condition, and thus whetlier or not lie should be adjudged responsible. ${ }^{122}$ In fact, Durham was explicitly decided to provide psychiatrists a wide

primarily cognitive tests without vohitional prongs because they held experts to lack the capacity to distinguish irresistible from merely unresisted impulses.").

115. Model Penal Code $\S 4.01$ comment 3 (Tent. Draft No. 1, 1953).

116. See S. GluECK, supra note 114 , at 53.

117. See id. at 51.

118. See M. MOORE, supra note 77, at 220, 223. More specifically, the New Hampshire court adopted the following language: "[]f the homicide was the offspring or product of mental disease in the defendant, he was not guilty by reason of insanity." State v. Pike, 49 N.H. 399, 442 (1870), overruled by Hardy v. Merrill, 56 N.H. 227 (1875). The District of Columbia court, which developed the Durham test, stated: "[A]n accused is not criminally responsible if his unlawful act was the product of inental disease or mental defect." Durham v. United States, 214 F.2d 862, 87475 (D.C. Cir. 1954), overruled by United States v. Brawner, 471 F.2d 969 (D.C. Cir. 1972).

119. See A. Goldstern, supra note 90 , at 83.

120. For an informative discussion of the development of these tests, see M. MOORE, supra note 77 , at 224-30.

121. See id. at $224,228$.

122. See id. at 226-28. 
purview of testimony to provide to the court; ${ }^{123}$ earlier tests such as $M$ 'Naghten were seen as insufficient because they prevented psychiatric witnesses from introducing evidence of disabling symptoms outside tlie peculiar criteria of the tests. ${ }^{124}$

Criticism of the Durham and New Hampshire tests, also called the product tests, focused on their failure to provide a clear standard by which a jury could judge the evidence presented-the same reasons that had initially recommended the test. ${ }^{125}$ Unlike the $M$ 'Naghten, irresistible inipulse, and A.L.I. tests, the product tests gave no patloological criteria for the jury to judge the defendant's mental condition. Instead, the jury was left to rely alinost exclusively on the expert witnesses' labeling of the act as a "product" of "mental disease." 126 One commentator notes that as the Durham test was applied in various cases, "it becane clear to the court that psychiatric conclusions about 'product' were often disguised moral judgments about tlie culpability of the accused,"127 and that this factor led the District of Columbia eventually to reject the Durham rule entirely, ${ }^{128}$ as the New Hampshire court had done nearly a century earlier. ${ }^{129}$

\section{Determining Mental Incapacity for Intentional Act Exclusion Clauses: The Current State of the Law}

In this Section, the Comment will show that courts dealing with insane insureds generally utilize mental and behavioral criteria from the criminal insanity tests in order to determine if an intentional act exclusionary clause serves to deny coverage for an insured's wrongful acts.

In recent years, Anerican courts have been divided into two distinct camps on the issue of insane insureds and the apphicability of intentional act exclusionary clauses. Basically, the first view holds that if an injury

123. See id. at 228.

124. See A. GoldsteIN, supra note 90 , at $82-83$ (noting that the Durham court felt that "symptom tests ... tend to freeze the law in conventional patterns and make it difficult for psychiatric witnesses to introduce new clusters of symptoms that might be equally disabling").

125. Id. at 84 .

126. Id.

127. M. MOORE, supra note 77, at 231. Elsewhere, Moore relates a remarkable example of the power psychiatrists had under the tests, in the story of psychiatrists at St. Elizabeth's Hospital. See Moore, supra note 68, at 37-38. These psychiatrists, who were often called to testify in Distriet of Columbia criminal trials, had made a policy decision that psychopathic and sociopathic disturbances would not be included as mental illnesses within the Durham rule. A weekend meeting at the hospital changed that policy, and the disturbances were declared to be mental illnesses for legal purposes. One of the consequences of the policy change was that the District of Columbia Court of Appeals awarded a new trial to a sociopathic defendant because the weekend change of nomenclature denied him new medical evidence vital to his defense. Id.

128. See United States v. Brawner, 471 F.2d 969 (D.C. Cir. 1972); M. MOORE, supra notc 77, at 230.

129. See Hardy v. Merrill, 56 N.H. 227 (1875). 
results from an insane act, the intentional injury clause is inoperative and the insurer is liable. ${ }^{130}$ The opposing view holds a narrower view of insanity, finding that an injury inflicted by an insane person may be termed intentional where the actor understands the physical nature and consequences of the act, even though he is imcapable of distinguishing right from wrong-a position even more restrictive than the M'Naghten test. ${ }^{131}$ Although tlie courts have been divided along these lines, some jurisdictions have shown little reluctance to alter and fine-tune the tests. The willingness to change the language used within the tests has introduced some confusion into this area of the law.

\section{Ruvolo and its Progeny: A Broad Definition of Insanity}

In 1963, the New Jersey Supreme Court handed down a decision which quickly became the leading case concerning the effect of insanity on the operation of intentional act exclusionary clauses im insurance policies. Ruvolo v. American Casualty Co. ${ }^{132}$ concerned a physician, Anthony Ruvolo, who shot and killed another physician with whom he had practiced medicine. At the time of the killing, Ruvolo had a personal hability insurance pohicy in effect, which was issued by the defendant insurer. This policy provided that the company would pay all sums that Ruvolo " 'shall become legally obligated to pay as damages' because of the death of any person resulting from [his] 'activities." "133 The coverage was limited by an exclusionary clause providing that the pohicy did not apply to death "caused intentionally by or at the direction of the insured." 134

The victim's widow filed a wrongful death suit, which Ruvolo's insurer refused to defend on the ground that the death had been caused by Ruvolo's imtentional act. The guardian of the insured then filed a declaratory judgment action against his insurer, seeking to establish that the pohicy afforded coverage. ${ }^{135}$ The insurer's defense was that the intentional act exclusion clause apphed. The trial court, relying upon psychiatrists' affidavits that Ruvolo was imsane at the time of the killing and lacked the capacity to form a rational intent to kill, granted summary judgment for the plaintiff. ${ }^{136}$ The trial court held that an act performed under such circumstances could not be considered an intentional act, and

130. See Globe Am. Casualty Co. v. Lyons, 131 Ariz. 337, 339, 641 P.2d 251, 253 (Ct. App. 1981).

131. See Johnson v. Insurance Co. of N. Am., 232 Va. 340, 346, 350 S.E.2d 616, 619-20 (1986); see also George v. Stone, 260 So. 2d 259, 261 (Fla. Dist. Ct. App. 1972).

132. 39 N.J. 490,189 A.2d 204 (1963).

133. Id, at 493, 189 A.2d at 206.

134. Id., 189 A.2d at 206.

135. Id. at 494, 189 A.2d at 206.

136. Id. at 495,189 A.2d at 207. 
as a result, the intentional act exclusion clause did not apply. ${ }^{137}$ The insurer appealed.

On appeal, the New Jersey Supreme Court first examined the issue of insanity and the operation of the exclusionary clause in the pohicy. Although noting that public pohicy prevents the indemnification of an insured from the consequences of his willful criminal act, and that exclusionary clauses achieve this aim, the court also pointed out that in applying such provisions "it has come to be cominonly accepted that where the death or loss involved ... is the product of an insane act, recovery is not barred [under the policy]."138 The court accepted the proposition that insanity would not trigger the exclusionary clause. It perceived that the case required it to formulate a test to determine whetlier the insured had the mental capacity to perform an act intentionally. ${ }^{139}$

The court concluded that if an insured would have been excused from responsibility under New Jersey's criminal standard, whicl was at that time the $M^{\prime}$ Naghten test, ${ }^{140}$ then the act was not intentional for the purposes of the insurance policy. ${ }^{141}$ But the court did not stop there. Noting that exclusionary clauses are drawn by experts working for the insurer, the court held that such clauses would be strictly construed against the insurer and that the insured was entitled to the most protection that any reasonable interpretation of the clauses would permit. ${ }^{142}$ The court stressed that where the conduct imsured against involves possible injury or damage to the public, this doctrime deserved especial emphasis. ${ }^{143}$ Thus, the court reasoned, coverage should not be limited to insureds who satisfy the M'Naghten definition. Instead, the court proposed an alternative test for cases im wlich the insured's inental capacity was in question:

[I]f the insured was suffering from a derangement of his intellect which deprived him of the capacity to govern his conduct in accordance with reason, and while in that condition acting on an irrational impulse he shot and killed [the victim], his acts cannot be treated as "intentional" within the connotation of defendant's insurance contract. ${ }^{144}$

The court went on to examine the trial court's grant of summary judgment to the plaintiff, determining that the lack of important factual details about Ruvolo's mental condition made granting suinmary judg-

137. Id. at 496,189 A.2d at 207.

138. Id., 189 A.2d at 207.

139. Id. at $496-97,189$ A.2d at 208.

140. Id. at 498, 189 A.2d at 208.

141. Id., 189 A.2d at 208.

142. Id., 189 A.2d at 208.

143. Id., 189 A.2d at 208-09.

144. Id., 189 A.2d at 209. 
ment inappropriate. ${ }^{145}$

The Ruvolo court's formulation of the test is an attempt to preserve insurance coverage for a group of insureds who would not meet the M'Naghten definition of insanity. Whereas the M'Naghten test covers only those individuals who suffer from a cognitive incapacity-that is, those who are unable to understand the nature and consequences of their act or its moral wrongfulness ${ }^{146}$ - the Ruvolo test provides a specific criterion for those insureds who are volitionally incapacitated and cannot control their actions.

The specific criterion for a finding of volitional incapacity emerges from the language of the test itself. For example, the phrase "capacity to govern his conduct" in the Ruvolo test appears to be equivalent to the phrase "capacity to conform conduct" used in the A.L.I. criminal standard. Although the phrasing of the A.L.I. test focuses on the capacity of the actor "to conform his conduct to the requirements of law,"147 while the Ruvolo test uses the phrase "in accordance with reason," 148 the emphasis on the volitional capacity of the actor remains the same in both. In addition, the Ruvolo test requires that the insured have acted upon an "irrational impulse" while in a volitionally incapacitated condition, which seems to be a concept drawn froin the irresistible impulse test. ${ }^{149}$

Yet a problematic ambiguity hes within the Ruvolo formnlation. One commentator lias suggested that the volitional and cognitive elements are superimposed within the phrase "deprived ... of the capacity to govern his conduct in accordance with reason," with the "capacity to govern" fragment indicating volitional capacity, and the "in accordance with reason" fragnient indicating cognitive capacity. ${ }^{150}$ Perceived this way, the test eliminates the M'Naghten standard from insurance litigation, simce an individual who lias the capacity to govern his conduct in accordance witli reason but does not do so because of a cognitive defect would not be found insane under the test. However, given the extensive discussion of the specifics of the M'Naghten test within the opinion and the court's statement that those insureds who met this definition would retain insurance coverage, it is not immediately clear why the court would replace the M'Naghten standard with a test appearing entirely volitional in emphasis. One possibility is that no such replacement was intended, but ratlier the volitional test was meant to be applied in con-

\footnotetext{
145. Id. at 500, 189 A.2d at 210.

146. See supra text accompanying notes 82-89.

147. See supra text accompanying note 104.

148. See supra text accompanying note 144 .

149. See supra text accompanying notes 96-100.

150. See Note, supra note 15 , at 1055-56.
} 
junction with the M'Naghten standard in order to provide coverage to insureds who qualify under the specific terms of either or both tests. If intended to supersede the M'Naghten test completely, the Ruvolo test is poorly drafted in that the cognitive function is at inost barely suggested by the phrase "in accordance with reason."

Despite this confusion, the Ruvolo test has been einployed in other cases. In George v. Stone, ${ }^{151}$ a Florida appellate court adopted the exact terminology of the New Jersey opinion ${ }^{152}$ and applied the test to a situation in which an insured shot and severely injured his inother-in-law's pliysician. ${ }^{153}$ The court overturned the trial court's summary judgnient in favor of the insurer, ${ }^{154}$ who had claimed that the insured's coverage was barred by an exclusionary clause excluding injury "caused feloniously or intentionally by or at the direction of an Insured,"155 and remanded the case for trial on the nerits.

Similarly, in Globe American Casualty Co. v. Lyons, ${ }^{156}$ the court found the Ruvolo reasoning persuasive as applied to an insured who had deliberately driven her car into an oncoming truck in an atteinpt to con1mit suicide. Quoting the doctrime of strict construction of exclusionary clauses against the insurer, ${ }^{157}$ and adding that the deterrent function of sucl clauses is poorly served by applying them to inentally incapacitated individuals, ${ }^{158}$ the court applied the Ruvolo test as follows: "[I]f [the insured] was suffering from mental derangenent which deprived her of her capacity to act in accordance with reason and while in that condition acted on an irrational consulsion to drive her vehicle into onconing traffic, her act was not 'intentional.' "159 The Arizona court made minor clianges in wording from the Ruvolo formulation. The Globe court replaced Ruvolo's requireinent of finding a "derangenient of [the] intellect," with the requirenent that there be "inental derangement." The Globe test used "act in accordance with reason" to replace Ruvolo's "govern . . . conduct in accordance with reason," and used "irrational compulsion" to replace Ruvolo's "irrational impulse." While the court did not explain these clianges, they do little or nothing to alter the meaning of the test.

Other courts have been influenced by the Ruvolo decision, but have

151. 260 So. 2d 259 (Fla. Dist. Ct. App. 1972).

152. See id. at 262 .

153. The insured also killed his bedridden mother-in-law and committed suicide. The wounded doctor brought the lawsuit. See id. at 260 .

154. Id. at 262.

155. Id. at 261.

156. 131 Ariz. 337, 641 P.2d 251 (Ct. App. 1981).

157. Id. at 339,641 P.2d at 253 .

158. Id. at 339-40, 641 P.2d at 253-54.

159. Id. at 340,641 P.2d at 254 . 
not followed the language of the test as closely as George or Globe did. In Rosa v. Liberty Mutual Insurance Co., ${ }^{160}$ decided by a federal court apparently applying Connecticut law, psychiatric testimony established that the insured had long suffered from severe schizophremia. ${ }^{161}$ The insured shot his victin twice during a rape attempt and liad shown significant planning activity before the crime, ${ }^{162}$ yet the court found that these purposeful actions were "traceable exclusively to the impairment of his judgment and rational capacity by tlie influence of schizophrenia." 163 Further, the "derangement of his intellect deprived him of the ability to govern his conduct in accordance with reason and intent, to judge the nature, character and consequence of his act and to resist the impulses to do other than what he did." 164 As a result, the insured's actions were not intentional within the meaning of the imsurance policy's exclusionary clause, which provided that coverage was not available for imjuries "c 'caused intentionally by . . . the Insured.' "165

Although the Rosa opimion cites tle $R$ uvolo decision, ${ }^{166}$ its formulation of an insanity test does not follow the $R$ uvolo test strictly, but ratlier contains a grab bag of eleinents from nearly all criminal standards. The Rosa test partially follows tle Ruvolo language in its finding that the insured suffered a "derangement of his intellect [which] deprived him of the ability to govern his conduct in accordance with reason . . .."167 However, the Rosa test expands upon Ruvolo's language, which seenis to apply only to individuals with volitional incapacities, by adding the specific language of the cogmitive and vohtional criteria drawn from traditional criminal standards: the insured was unable to judge the nature, character, and consequences of his act, was unable to govern his conduct in accordance with reason, and was unable to resist the impulse to commit the act. ${ }^{168}$ Additionally, the opinion suggests the influence of the Durham and New Hampshire product tests in finding that the crime was traceable exclusively to the insured's schizophrenia. ${ }^{169}$

In Congregation of Rodef Sholom v. American Motorists Insurance

160. 243 F. Supp. 407 (D. Conn. 1965).

161. See id. at 409.

162. According to the opinion, the insured had borrowed a gun, purchased ammunition, and left home to search for a girl "so that he could have sexual relations with her, and that he had been thinking about having intercourse with a girl for 'a few months." II. at 408.

163. Id. at 409 .

164. Id.

165. Id. at 408 .

166. Id. at 409.

167. Id.

168. Id.

169. See id. (" $[T]$ he Court finds all his activities leading up to the attack on the plaintiff, and the attack itself, are traceable exclusively to the impairment of his judgment and rational capacity by the influence of schizophrenia."). 
Co., ${ }^{170}$ a California court took a similar approach: the opinion discusses Ruvolo and approves of the policy considerations behind the test, but departs from the Ruvolo standard significantly in formulating its own test. The insured in Rodef Sholom was a sixteen-year-old boy who set a fire in a wastebasket in a classroom. The fire spread and caused substantial damage to the building. ${ }^{171}$ The boy had been under the care of a psychiatrist, who testified in court that the boy was suffering froin a "schizoid personality caused by mental disease" at the time of his act and that an irresistible impulse forced him to set the fire. ${ }^{172}$ The trial court held that the intentional act exclusion in the insured's policy applied unless the insured's conduct demonstrated legal insamity under the M'Naghten test, then the criminal standard in Califormia. ${ }^{173}$ Under that standard, the jury found the boy to be sane. ${ }^{174}$

The appeals court disagreed with the trial court's use of the M'Naghten test. Discussing Ruvolo, the court highlighted the policy considerations underlying the decision: exclusions should be strictly construed against the insurer, and this doctrime applies with special emphasis when the insured-against conduct involves injury to the public. ${ }^{175}$ Although noting that the exclusion of intentional acts fron coverage stems from a belief that an individual should be financially responsible for the consequences of his intentional acts, the court stated that an individual who lacks substantial capacity to conform his conduct to the law will not be influenced by the existence of insurance. ${ }^{176}$ Furthermore, the public's strong interest in the compensation of victins reinforces the primciple that exclusionary clauses be interpreted as narrowly as possible. ${ }^{177}$ Accordingly, the court concluded that the "concept of insanity" relevant to insurancc exclusions should be broader than that provided by the M'Naghten test. ${ }^{178}$

The court then noted that altliough the A.L.I. test of criminal insanity "more nearly comports to tlie proper rule than does M'Naghten," 179 neither standard was appropriate in the insurance context. Instead, the court apphed the following rule:

If [the insured] was suffering from a mental disease or defect which deprived him of capacity to intend to set the fire and cause the damage complained of, or which deprived him of the capacity to govern his con-

170. 91 Cal. App. 3d 690, 154 Cal. Rptr. 348 (1979).

171. Id. at 692, $154 \mathrm{Cal}$. Rptr. at 349.

172. Id. at 693-94, $154 \mathrm{Cal}$. Rptr. at 349-50.

173. Id. at 694, 154 Cal. Rptr. at 350.

174. See id. at 694-95, $154 \mathrm{Cal}$. Rptr. at 350.

175. See id. at 697, 154 Cal. Rptr. at 352.

176. Id., 154 Cal. Rptr. at 352.

177. Id., 154 Cal. Rptr. at 352.

178. Id., $154 \mathrm{Cal}$. Rptr. at 352.

179. Id., $154 \mathrm{Cal}$. Rptr. at 352. 
duct in accordance with reason, then he did not act intentionally as that word is used in the exclusionary clause in [the insurer's] policy of insurance. ${ }^{180}$

Rodef Sholom departs from Ruvolo in several ways. First, it returns to the traditional criminal test requirement of a "mental disease or defect," as opposed to Ruvolo's broader "derangement of the intellect" requireinent. The Rodef Sholom test is very clear in its separation of the cognitive and volitional criteria. The cognitive criterion is embodied in the "capacity to intend" phrase, and the volitional criterion is embodied in the "capacity to govern conduct" phrase. In this respect, the Rodef Sholom test is clearer than the Ruvolo test because it uses specific language to encompass both cognitively and volitionally incapacitated insureds.

Another group of tests shows the influence of the Ruvolo decision but does not use its specific language or that of any of the other related tests. Rather, these tests simply state that exclusionary clauses do not apply where an insured is insane or lacks the inental capacity to form an intent. For example, in Nationwide Mutual Fire Insurance Co. v. Turner, ${ }^{181}$ the court held that "an insane individual cannot commit an intentional act within the meaning of an intentional injury exclusion clause."182 No further criteria were presented by the court; "msanity" remaims essentially undefined, without the specific cognitive and vohtional elements employed by other tests. ${ }^{183}$

\section{Wagner and Its Progeny: Insanity Defined in Terms of Cognitive siwareness}

The line of authority in opposition to Ruvolo defines insamity in much narrower terms. The leading case is Colonial Life \& Accident Insurance Co. v. Wagner, ${ }^{184}$ decided im Kentucky a year after Ruvolo. In

180. Id. at $697-98,154$ Cal. Rptr. at 352.

181. 29 Ohio App. 3d 73, 503 N.E.2d 212 (1986).

182. Id. at 76, 503 N.E.2d at 217.

183. See also Mangus v. Western Casualty \& Sur. Co., 41 Colo. App. 217, 220, 585 P.2d 304, 306 (1978) ("[w]here an insurance policy excludes liability coverage for intentional acts and the insured has committed an assault and battery while insane, the insured's insanity, as a matter of law, precludes the exclusion from being activated"); Northland Ins. Co. v. Mautino, 433 So. $2 \mathrm{~d} 1225$, 1227 (Fla. Dist. Ct. App. 1983) ("An insane person cannot be deemed to have acted intentionally for purposes of an intentional tort exclnsion clause in an indemnification policy."), appeal denied, 447 So. 2d 887 (Fla. 1984); Arkwright-Boston Mfrs. Mut. Ins. Co. v. Dunkel, 363 So. 2d 190, 193 (Fla. Dist. Ct. App. 1978) ("[W]e hold, as did our sister court in the similar case of George v. Stone, that an insane individual cannot commit an intentional act within the meaning of an "mtentional injury exclusion clanse." ") (citation omitted); Aetna Casualty \& Sur. Co. v. Dichtl, 78 Ill. App. 3d 970, 978, 398 N.E.2d 582, 588 (1980) ("[The insured's] conduct would not fall within the exclusion if, at the time she inflicted the injuries upon [the victim], she lacked the mental capacity necessary to form the intent to injure him or the expectation of his injury.").

184. 380 S.W.2d 224 (Ky. 1964). 
Wagner, the insured was an einployee of a hotel that had a group insurance pohicy. That pohicy excluded coverage for "death or other loss caused or contributed to . . . by injuries intentionally inflicted upon the Insured Employee by any other person."185 The insured, Warren Wagner, was shot and killed by a man who claimed that his mental condition was such that he could not intentionally commit the offense. Testimony was presented that the killer "got spells where he did not know what he was doing,"186 and a psychology professor who had interviewed the killer inaintained that the inan was incapable of forming a rational intention to perform the act. ${ }^{187}$ The court noted, however, that when the killer himself was asked whether the killing was intentional, he repeatedly replied that it was. ${ }^{188}$ In addition, there was evidence that the killer liad threatened the life of the victim prior to the attack. ${ }^{189}$

The trial jury was instructed that the exclusion clause did not apply if they believed that the killer did not have sufficient mind or intellect to know the difference between right and wrong, or to form a rational intent to shoot the insured. ${ }^{190}$ They were instructed that the clause did apply if they found that the gunshot wounds were intentionally inflicted. ${ }^{191}$ The jury returned a verdict for the victim's widow. The court of appeals remanded for a new trial, holding that if the evidence presented was substantially the same, the trial court should direct a verdict for the insurer. ${ }^{192}$ In support of its conclusion, the court distinguished between the nonapplication of criminal sanctions to an insane person and the finding that there was no intention behind the act:

In law, there are many conditions under which a person may imtentionally kill and not be subject to criminal punishment. A man may kill in self-defense. .. . The executioner may kill with the sanction of the State. All of this destruction is intentional, but excusable. Similarly a person inay be excused froin penalty if he is insane at the time he commits a criminal act. He may do the act with every intention of consummating it, but if it is shown that he was mentally insufficient, he is excused from the imposition of the usual sanctions. The absence of punishment, however, does not retrospectively expunge the original intention. ${ }^{193}$

The court went on to discuss another case, Deloache v. Carolina Life

185. Id. at 225 .

186. Id.

187. Id. at 225-26.

188. Id. at 225 .

189. Id at 226 .

190. Id.

191. Id.

192. Id. at 227.

193. Id. at 226. 
Insurance Co., ${ }^{194}$ which had held that whether an insured was mentally or legally responsible for his act was irrelevant for the purposes of insurance coverage. ${ }^{195}$ The Wagner court accepted the Deloache reasoning and held that under the terms of the policy at issue, the act was imtentional and therefore specifically excluded from the policy coverage. ${ }^{196}$ In a second appeal, the court stated its conclusion im even stronger terms: "[I]rrespective of whether [the killer] was insane, the gunshot wounds which caused the death of the assured were 'intentionally inflicted' as this term is used in the pohicy."197

In effect, Wagner maintained that an insane person, though possibly so mcapacitated that he could not judge right from wrong, was nevertheless capable of forming an intention to perform an act. It further suggested that if an insane person was at least rational enough to understand the nature of the act he was performing, then he was acting "intentionally" for the purposes of insurance coverage, even though his mental condition may not have allowed any other sort of intellectual functioning. Compared to the existing criminal tests of insanity, this test went beyond even the narrow cognitive view of the M'Naghten standard; it spht off the "understanding the nature and consequences" criterion from the "right and wrong" criterion, and discarded the latter.

The Wagner position was not an original one in the insurance context; it had been implied in earlier cases such as Rider $v$. Preferred Accident Insurance Co. ${ }^{198}$ and Pruitt v. Life Insurance Co. of Virginia. ${ }^{199}$ In Rider, an insured was shot and killed by a man allegedly incapable of distinguishing right from wrong. The appellate division overturned a verdict in favor of the insured victim's widow and directed a verdict in favor of the insurer, stating, "The undisputed evidence of the experts ... is to the effect that [the killer], though insane, intended to shoot, and injure or kill, the insured; that he understood the physical consequences and results of such shooting." 200 The Pruitt court similarly held that the evidence presented was "wholly insufficient to show that [the killer] ... was so insane as not to know right from wrong. But it is idle to pursue that line of thought, because it remains proved that [the killer] intentionally stabbed [the insured] ...."201 The effect of these decisions is to

194. 233 S.C. 341 , 104 S.E.2d 875 (1958).

195. See Wagner, 380 S.W.2d at $226-27$ (citing Deloache, 233 S.C. at $341,344,104$ S.E. $2 d$ at 875, 876).

196. Id. at 227.

197. Wagner v. Colonial Life Accident Ins. Co., 408 S.W.2d 612, 612 (Ky. 1966) (emphasis added).

198. 183 A.D. 42,170 N.Y.S. 974 (1918), aff'd, 230 N.Y. 530, 130 N.E. 881 (1920).

199. 182 S.C. 396,189 S.E. 649 (1936).

200. Rider, 183 A.D. at 44,170 N.Y.S. at 975 (emphasis added).

201. Pruitt, 182 S.C. at 398,189 S.E. at $649-50$. 
narrow the definition of insanity for the purposes of intentional act exclusionary clauses to a single eleinent: incapacity to understand the physical nature and consequences of an act. This definition of insanity is much narrower than definitions in the Ruvolo line which cover both cognitive and vohtional incapacities.

Wagner, Deloache, and Pruitt all concerned an insured who was the victim, not the perpetrator, of an insane act. Nonetheless, the reasoning of these cases has been applied to situations in which the insured claims insanity to avoid the operation of an exclusionary clause. In Rajspic $v$. Nationwide Mutual Insurance Co. (Rajspic $I$ ), ${ }^{202}$ the insured shot and injured the victim during an altercation. At her criminal trial, the insured was acquitted of assault with a deadly weapon on the grounds of insanity, and in a later civil suit brought by the victim, it was stipulated that the insured was legally imsane at the time of the shooting. ${ }^{203} \mathrm{~A}$ verdict was entered for the victim, but the insurer refused to pay the judgment, claiming the act fell within the intentional act exclusionary clause in the insured's policy. ${ }^{204}$ The insured brought suit against the insurer for payinent, and at trial the court refused the insurer's motion to exclude evidence of the stipulation. ${ }^{205}$ Instead, the trial court applied collateral estoppel based on the stipulation to the insured's insanity, and granted summary judgnent for the insured on hability. ${ }^{206}$ The insurer appealed the summary judgnient. ${ }^{207}$

In its analysis, the Supreme Court of Idaho first considered whether a person characterized as insane was capable of forming the intent necessary to commit an intentional tort, or whose actions, in the terins of this case, "could be considered within the imtentional acts exclusion of the insurance pohicy at issue." 208 The court concluded that imsane persons could commit intentional acts, ${ }^{209}$ agreeing with the following stateinent froin a Massachusetts insurance case that denied insurance coverage:

A person may be insane, entirely incapable of distinguishing between right and wrong, and without any just sense of moral responsibility, and yet retain sufficient powers of mind and reason to act witl preeneditation, to understand and contemplate the nature and consequences of his own conduct, and to intend the result which his acts are calculated to produce. ${ }^{210}$

202. 104 Idaho 662, 662 P.2d 534 (1983).

203. Id., $662 \mathrm{P} .2 \mathrm{~d}$ at 534.

204. Id. at $663,662 \mathrm{P} .2 \mathrm{~d}$ at 535 .

205. Id., 662 P.2d at 535 .

206. Id., 662 P.2d at 535 .

207. Id., 662 P.2d at 535 .

208. Id., 662 P.2d at 535 .

209. Id., $662 \mathrm{P} .2 \mathrm{~d}$ at 535 .

210. Id. at 664,662 P.2d at 536 (quoting Dean v. American Mut. Life Ins. Co., 86 Mass. (4 Allen) 96,100 (1862)). 
Thus, as the court stated, insanity under the law is not dispositive of whether the insured committed an intentional act within the scope of the policy exclusion. ${ }^{211}$ Therefore, the insanity of the insured for the purposes of the policy presented a question of fact. The court also overturned the trial court's application of collateral estoppel to the issue of the insured's insanity, holding that counsel's stipulation of insanity at the civil trial denied the insurer a full, fair opportunity to litigate the issue. ${ }^{212}$ The court renianded the case to the trial court for litigation of the issue of insanity. ${ }^{213}$

The case was appealed again in Rajspic II, ${ }^{214}$ whereupon the court repeated its earher conclusion that "an otherwise insane person inay have sufficient capacity to understand and conteniplate the nature and consequences of her actions."215 The court noted that other cases, such as Ruvolo, ${ }^{216}$ Globe, $^{217}$ and Rosa, ${ }^{218}$ had leeld that as a inatter of law an insane person cannot intentionally cause injury as excluded in insurance policies. ${ }^{219}$ The court did not adopt this position, ${ }^{220}$ but did state that in order for the exclusion clause to apply, the insurer would have to prove that the insured was capable of forming the intent to injure the victim. ${ }^{221}$ The Rajspic II court did nothing, though, to alter its previous position that an insane person can act intentionally if she understands the nature and consequences of her acts. In this respect, the Rajspic opinions follow the Wagner reasoning and suggest that a minimal level of cognitive awareness is sufficient to estabhish an intention for the purposes of insurance exclusions.

This "minimal level of awareness" concept was explored in more deptl in a recent Virginia case, Johnson v. Insurance Co. of North America. ${ }^{222}$ The insured in Johnson shot his victim after planning the act, awaitnig the victini's arrival loone, and later conversing with him. ${ }^{223}$ During the trial, which was initiated by the insurer on a bill of coinplaint for declaratory judgnient, ${ }^{224}$ three mental health professionals testified that the insured said he believed the victinı was projecting voices into his

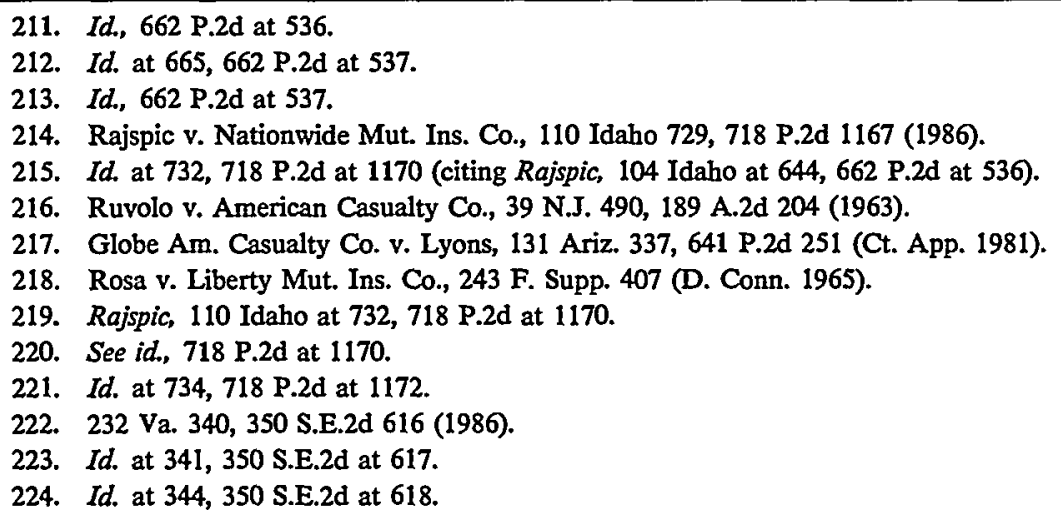


mind, preventing him from hearing the voice of God. ${ }^{225}$ They also testified that the insured told thein that on the day of the shooting, God had commanded him to kill the victim and he had obeyed God's order. ${ }^{226}$ The trial court concluded that the exclusionary clause in the insured's policy applied, noting that " "even though [the insured] was inentally ill, he was aware of his actions and of the consequences of those actions. ... [The insured] inay have been prompted by or acting under delusional behiefs, but he was aware of what he was doing and intended the resulting injury." "227

The Supreme Court of Virginia affirmed the trial court judginent, agreeing that the insured's actions, though driven by delusion, were intentional. ${ }^{228}$ To support this seemingly internally inconsistent notion, the court noted that the two elements of the M'Naghten rule, which it termed the "nature-of-the-act test" and the "right-wrong" test, can logically be separated. ${ }^{229}$ The court found that when the insured shot the victim, he knew he was shooting at a huinan being, and acted deliberately and methodically in doing so. ${ }^{230}$ As the court stated, "He acted with resolve and determination, not knowing that what he was doing was wrong because God had ordered him to act."231 The court held that the minimal degree of awareness the insured possessed "was sufficient to establish that the shooting was intentional, and therefore the insurance exclusion regarding intentional acts applied. ${ }^{232}$

The court denied any weakness of its holding, insofar as an insured might be deemed insane under criminal law, yet be denied insurance coverage because he was found capable of forming an intent under insurance law. ${ }^{233}$ Quoting Wagner, the court stated that the refusal to apply criminal sanctions to an insane person " "does not retrospectively expunge the original intention." "234

Johnson provides the inost detailed exposition of the position adopted by the Wagner line of cases. Regardless of the total nature of an insured's insanity, those courts only applied a test analogous to the first element of the M'Naghten rule-whether the insured was capable of understanding the nature and consequences of his acts. That capabihity of the insured determines whether his act was intentional for the pur-

\footnotetext{
225. Id. at 342,350 S.E.2d at 617 .

226. Id., 350 S.E.2d at 617 .

227. Id. at 345,350 S.E.2d at 619 (quoting the memorandum opinion of the trial court).

228. Id. at $347-48,350$ S.E. $2 \mathrm{~d}$ at $620-21$.

229. Id. at 347,350 S.E.2d at 620 .

230. Id., 350 S.E. $2 \mathrm{~d}$ at 620 .

231. Id., 350 S.E.2d at 620 .

232. Id. at 348,350 S.E. $2 \mathrm{~d}$ at $620-21$.

233. Id., 350 S.E. $2 \mathrm{~d}$ at $620-21$.

234. Id., 350 S.E.2d at 621 (quoting Colonial Life \& Accident 1ns. Co. v. Wagner, 380 S.W.2d 224, 226 (Ky. 1964)).
} 
poses of exclusionary clauses. Courts ignore other factors, such as the capacity to distinguish right from wrong, or the ability to desist from performing the wrongful act-favoring instead a narrowly defined level of coguitive awareness.

\section{III}

\section{The Argument Against the Existing Tests}

In Part I, this Comment discussed exclusionary clauses, the public policies and doctrines behind insurance law, and the determination of intent where insanity is not at issue. Part II described the different approaches taken toward insanity in the tort and criminal contexts, and listed the various tests implemented in criminal courts to determine whether the defendant is insane. Finally, this Comment discussed the tests for insanity as they have evolved in the insurance context, demonstrating that they are rooted in the tests developed in the criminal context.

In this Part, the Comment will argue that the various tests used to determine insanity in the insurance context are flawed for a number of reasons. First, certain tests are underinclusive in that they deny coverage to large numbers of msureds who are unable to control their actions. Other tests are overinclusive in that the criteria they apply are too vague, are overly dependent upon psychiatric testimony, and could be construed to cover voluntary intoxication. This Section of the Comment will examine the existing insurance insanity tests and describe the sources of their weaknesses.

\section{A. Problems With the "Derangement of the Intellect" Test}

The primary problem with Ruvolo v. American Casualty Co. ${ }^{235}$ and the cases following its test, such as George v. Stone, ${ }^{236}$ Globe American Casualty Co. v. Lyons, ${ }^{237}$ and Rosa v. Liberty Mutual Insurance Co., ${ }^{238}$ lies in the substitution of "derangement of the intellect" or "mental derangement" for the more traditional "mental disease or defect." Admittedly, estabhishing the proper legal definition of "inental disease," which is essentially a medical/psychiatric concept, is problematic. ${ }^{239}$ However, the crucial difference between the phrases "derangement of the intellect" and "mental disease or defect" is that under the former, an insured's voluntary imtoxication through drugs or alcohol could possibly

235. 39 N.J. 490, 189 A.2d 204 (1963).

236. 260 So. $2 d 259$ (Fla. Dist. Ct. App. 1972).

237. 131 Ariz. 337, 641 P.2d 251 (Ct. App. 1981).

238. 243 F. Supp. 407 (D. Conn. 1965).

239. See infra text accompanying notes 273-82. 
qualify, whereas under the latter it could not. ${ }^{240}$

The Ruvolo court did not explain why it used the phrase "derangement of the intellect," nor did it suggest that the phrase might cover voluntary intoxication. Instead, the court rehed on two traditional doctrines of imsurance law and focused on the underlying public policy the doctrines were designed to serve. The court relied on the following: (1) exclusion clauses should be strictly construed against the msurer, and (2) an insured is entitled to as much protection as a reasonable interpretation of the clause permits. ${ }^{241}$ The court explained its reliance on these doctrines by emphasizing that their underlying purpose-protecting members of the public-was particularly forceful where, as here, the insured's mental incapacity would absolve lim of criminal responsibility. ${ }^{242}$

Some commentators argne that mcluding voluntary intoxication

240. See Note, supra note 15 , at 1052 . This result might not be objectionable if one adopts the widely accepted view of alcoholism and drug addiction as diseases. See generally H. FINGARETTE \& A. HASSE, supra note 88, at 144-48, 186-90 (discussing the labeling of addiction as a disease). Under this view, the conduct of an alcoholic or drug addict is perceived as involuntary. See id. at 152-53. Addiction, then, could be included under the traditional rubric "mental disease or defect," because like schizophremia or mental retardation, it is involuntarily caused and maintained. However, the view of narcotics addiction and especially of alcoholism as diseases has been subject to withering attack from commentators inside and outside the medical profession. See id. at 146 n.41, 189 n.60. A recent attack was inade by the Supreme Court in Traynor v. Turnage, 485 U.S. 535 (1988), where the Court upheld a Veteran's Administration regulation that classified alcoholism as "willful misconduct." Id. at 550-51. Fingarette and Hasse themselves conclude that "there is no medical foundation for adopting the general proposition . . that addictive conduct is involuntary." $H$. FINGARETTE \& A. HASSE, supra note 88, at 191. Moreover, as they point out, "massive descriptive evidence indicates that individuals often inake choices to abandon addictive conduct or abstain froin drug or alcohol use permanently or tempotarily." Id. This Comment does not intend to enter into complex arguments about such conditions and their medical/legal rainifications. Recognizing, however, that the root question concerning the effect of intoxication on insurance coverage is its classification as voluntary or involuntary, this Comment takes the position of Fingarette and Hasse and concludes that addictive behavior is in its essence voluntarily undertaken, since even people genetically predisposed to thosc diseases can choose not to drink or use drugs. Sueh choice-driven behavior should not be deemed equivalent to truly involuntary conditions like schizophrenia or mental retardation, which are recognized as true mental diseases. This argument, of course, does not apply to situations where an insured has become intoxicated involuntarily (as, for exainple, a person whose drimk has been spiked) or those individuals who react to drugs ingested pursuant to medical advice.

241. Ruvolo v. American Casualty Co., 39 N.J. 490, 498, 189 A.2d 204, 208-09 (1963).

242. Id., 189 A.2d at 208; see also Globe Am. Casualty Co. v. Lyons, 131 Ariz. 337, 339-40, 641 P.2d 251, 253-54 (Ct. App. 1981) ("[T] deny coverage for acts caused by an individual lacking the mental capacity to act rationally is inconsistent with a primary purpose for incorporating intentional injury exclusions into insurance policies .... An individual who lacks the capacity to conform his behavior to aceeptable standards will not be deterred by the existence or nonexistence of insurance coverage for the consequences of his acts."); George v. Stone, 260 So. 2d 259, 262 (Fla. Dist. Ct. App. 1972) ("The principle [that a person who is legally insane cannot be said to have acted intentionally for the purposes of imtentional injury exclusion clauses] comports with the guiding principle of insurance law that exclusionary provisions are to be strictly construed against the insurer, and in favor of providing coverage in order that the purpose of insurance not be defcated."). 
within the meaning of "mental incapacity" is in harmony with the provictim focus of insurance law, in that it provides coinpensation to innocent victims "regardless of the origin of the assailant's mental derangement."243 The language of Ruvolo has been used to reach just this result in some case law. For example, in Burd v. Sussex Mutual Insurance Co. ${ }^{244}$ the same court that had decided Ruvolo seven years earlier used Ruvolo to deny application of an intentional act exclusion clause to acts committed by a voluntarily imcapacitated insured. ${ }^{245}$ In Burd, the insured was sued by the man he had shot while voluntarily intoxicated. ${ }^{246}$ The insurer refused to defend on the grounds that the intentional act exclusion clause applied. ${ }^{247}$ The New Jersey Supreme Court cited Ruvolo for the proposition "that the concept of imsanity relevant to the exclusion clause of a liability policy [is] more expansive than the concept of insanity accepted in the defense of a criminal charge."248 Following this logic, the court held that the insurer bore the burden of proving that the insured, notwithstanding his intoxication, formed the intent to injure his victim. ${ }^{249}$

This position dangerously skews the focus of insurance from the coverage of fortuitous acts beyond the control of the insured, ${ }^{250}$ toward protection against the financial consequences of the insured's choice to ingest drugs or alcohol, essentially making such conduct "risk-free." One of the reasons behind intentional act exclusionary clauses is the public's interest in deterring dangerous behavior. ${ }^{251}$ If the results of voluntary intoxication are outside the effect of such a clause, as arguably they are under the Ruvolo "derangement of the intellect" language, the deterrence rationale is completely defeated. The drug and alcohol problems im the Umited States powerfully argue agamst sucl a policy choice.

Recent reports imdicate that the abuse of alcohol and other illegal

\footnotetext{
243. Note, supra note 15 , at 1054 .

244. 56 N.J. 383, 267 A.2d 7 (1970).

245. See id. at 398-99, 267 A.2d at 15.

246. Id. at $386,398,267$ A.2d at 9, 15.

247. Id. at $387,267 \mathrm{~A} .2 \mathrm{~d}$ at 9 .

248. Id. at $399,267 \mathrm{~A} .2 \mathrm{~d}$ at 15 .

249. Id., 267 A.2d at 15 . Other courts have also refused to apply exclusion clauses to insureds who commit torts while voluntarily intoxicated. See, eg., State Farm Fire \& Casualty Co. v. Morgan, $185 \mathrm{Ga}$. App. 377, 364 S.E.2d 62 (1987) (adopting the view that if an insured is so intoxicated as to be unable to know, understand, and intend to do the act, the act is not intentional), aff'd, $258 \mathrm{Ga} .276,368$ S.E.2d 509 (1988); Garden State Fire \& Casualty Co. v. Keefe, 172 N.J. Super. 53, 410 A.2d 718 (App. Div.) (relying on Burd to state in dicta that voluntary intoxication can negate intent within the ineaning of an insurance policy), appeal denied, 84 N.J. 389, 420 A.2d 317 (1980); Kenna v. Griffin, 4 Wash. App. 363, 481 P.2d 450 (1971) (holding that while intoxication can diminish intent, the trial court properly found that the insured was not so affected by alcohol that he could not form the requisite intent).

250. See supra text accompanying notes 1 \& 8 (discussing the purpose of insurance coverage).

251. See R. JERRY, supra note 26, at 313; see also supra text accompanying notes 12-16.
} 
drugs is not limited to a small proportion of Americans: substance-abuse disorders affect $3.8 \%$ of the population at any given time, and can be expected to affect $16.4 \%$ of all adults at some time during their lives. ${ }^{252}$ Alcoliol abuse is overwhelmingly more common than abuse of all other drugs combined, ${ }^{253}$ but cocaine usage is rapidly becoming a problem of enornous proportions. Cocaine usage doubled between 1982 and 1987, when 5.2 million Americans reportedly ingested the drug. ${ }^{254}$ One year later, the White House Conference for a Drug-Free America estimated that 6 million Americans were cocaine users. ${ }^{255}$

The American Psychiatric Association's Diagnostic and Statistical Manual of Mental Disorders contains descriptions of symptoms that are induced by the consumption of various intoxicating substances. ${ }^{256}$ For example, alcoliol intoxication can create aggressiveness, impaired judgment, irritability, and is frequently associated with the commission of criminal acts includimg murder. ${ }^{257}$ Cocaine intoxication can result in figliting, persecutory delusions, and aggressive or violent action against perceived enemies. ${ }^{258}$ Cocaine and other illegal drugs have, like alcolıol, been linked to the commission of criminal acts. ${ }^{259}$

Reports indicate that the inclusion of voluntary intoxication among the conditions vitiating intentional act exclusionary clauses could have a substantial impact on insurers, opening them up to widespread liability. ${ }^{260}$ Moreover, the coverage of damages arising from voluntary intoxication directly conflicts with the well-establislied judicial policy of preventing tortfeasors from insuring against their own intentional wrongdoing. ${ }^{261}$

Several courts liave empliasized this policy in interpreting exclusion clauses where the insured was intoxicated at the time of his tortious conduct. In Allstate Insurance Co. v. Sherrill, ${ }^{262}$ the court lield that an insured may not assert a defense to an exclusionary clause based on lack

252. Parachini, Probing the State of Our Minds, L.A. Times, Nov. 1, 1988, § 5, at 1, col. 4.

253. Id.

254. See War on Drugs Makes Little Headway, U.S. News \& World Report, June 22, 1987, at 35 .

255. Kearns, Conference Calls for U.S. Drug Czar, Harsher Penalties, Reuters, June 21, 1988.

256. See American Psychiatric Ass'n, Diagnostic and Statistical Manual of Mental Disorders (rev. 3d ed. 1987).

257. Id. at 127-28. More than one-half of all murderers and their victims are believed to have been intoxicated at the time of the act. Id. at 128 .

258. Id. at 141-44.

259. In 1986, about $35 \%$ of the nation's state prison inmates had been under the influence of an illegal drug at the time they committed the crimc for which they were incarcerated. Drugs, Crime Found More Closely Tied, L.A. Times, July 11, 1988, § 1, at 2, col. 3.

260. Such coverage can also be seen as a "moral hazard." See supra note 11 and accompanying text.

261. See supra notes 12-16 and accompanying text.

262. 566 F. Supp. 1286 (E.D. Mich. 1983) (applying Michigan law). 
of capacity to form an intent, when that lack of capacity is solely based on the voluntary ingestion of alcohol and/or drugs. ${ }^{263}$ In reaching its conclusion, the court stated that "[p]ublic policy demands that a voluntary departure of one's good judgment and rational decision-making abilities should not permit the insured to abrogate his financial responsibility to those he brutally injures."264 Similarly, in Hanover Insurance Co. v. Newcomer, ${ }^{265}$ the court affirmed a lower court's ruling that the intentional act exclusionary clause apphed to the physical assault committed by the intoxicated insured. ${ }^{266}$ Determining that the intent to harm could be inferred from the insured's act of wildly swinging a machete, the court stated that although the evidence established that he was under the influence of intoxicants and marijuana, this evidence was "of no consequence, for the law must not permit the use of such stimuli to become a defense for one's actions." 267

Voluntarily intoxicated insureds must not have the ability to commit a wrongful act while protecting themselves from the civil consequences; incapacitation due to the mgestion of alcohol and drugs should not be equated with incapacitation due to the presence of an endemic mental disease or defect. The public policy of deterrence of tortious acts has little force when the insured is mentally ill, as it is unlikely that a mentally ill insured would be influenced at all by the existence of insurance coverage. However, in the situation of voluntary intoxication, the deterrence rationale retains its persuasive force. Because the "derangement of the intellect" language in Ruvolo and other cases suggests that drug- or alcohol-incapacitated insureds who liarm others can avoid the operation of an intentional act exclusionary clause, that language is in direct conflict with the foregoing line of reasoning and should be rejected. ${ }^{268}$

263. Id. at 1288.

264. Id.

265. 585 S.W.2d 285 (Mo. Ct. App. 1979).

266. Id. at 289.

267. Id,; see also Travelers Ins. Co. v. Cole, 631 S.W.2d 661 (Mo. Ct. App. 1982) (holding that the insured's ingestion of alcohol, ampicillin, and codeine was of no consequence); American Family Mut. Ins. Co. v. Peterson, 405 N.W.2d 418 (Minn. 1987) (holding that the reasonable expectations of the insured about his policy coverage would not include assaults committed while voluntarily intoxicated, and reasoning that an insured should not be given any hicense to conmit malicious acts).

268. Sone comnentators have advocated allowing insurers the right of subrogation against the insured in situations where an innocent person is injured by an insured who was voluntarily intoxicated or otherwise committed an intentional act. See Note, supra note 15, at 1054; Case Comment, supra note 12, at 169 . This solution has been touted as resolving the conflict between the policies of compensating the victim on the one hand, and deterring wrongful conduct by the insured on the other. See Note, supra note 15 , at 1054. The solution has received some limited case support, most notably in Ambassador Insurance Co. v. Montes, 76 N.J. 477, 388 A.2d 603 (1978), where the New Jersey Supreme Court granted an insurer a right of subrogation agaimst an insured who had set fire to his insured building and killed several people.

However, such a right to subrogation is a dramatic departure from established doctrine: 


\section{B. The "Non-Rule" Rules}

Very different probleıns arise in cases presenting no specific standards for evaluating an insured's insanity. In contrast to cases such as Ruvolo, ${ }^{269}$ Rodef Sholom, ${ }^{270}$ Globe, ${ }^{271}$ and George, ${ }^{272}$ which present specific cognitive and vohtional criteria to judge an insured's inental condition, the opinions in cases such as Turner, ${ }^{273}$ Arkwright, ${ }^{274}$ Dichtl, ${ }^{275}$ Mangus, ${ }^{276}$ and Mautino ${ }^{277}$ give no inore guidance than a stateinent that an insane insured cannot act intentionally for the purposes of exclusionary clauses. ${ }^{278}$ The problein with these cases is not in the interpretation of various mental or behavioral criteria, but rather that they do not provide any criteria at all. As a consequence, these cases trigger inany of the same issues surrounding the New Hanipshire and Durham tests for criminal insanity, which also provide no specific cognitive or volitional guidelines for the jury to use to determine insanity. ${ }^{279}$ The theory behind the New Hampshire and Durham tests was that psychiatrists, who are the experts at determining insanity, should be allowed a wide purview of testiniony, but in practice psychiatrists were deciding the legal standards for insanity on an ad hoc basis without any kind of review. ${ }^{280}$

Like the Durham and New Hampshire tests, insurance cases that

ordinarily, no right of subrogation can arise in favor of an insurer against its own insured. By definition, an insurer has a right of subrogation only against third persons, to enforce rights of the insured. Ordinarily, courts do not grant an insurer any rights of subrogation as against the insured. $16 \mathrm{~J}$. Couch, CycLopedia of INSURANCE LAW § 61:136 (R. Anderson rev. 2d ed. 1983). In addition, the case support that does exist for such a position is problematic. The holding in Montes has been limited to situations in which the insured's policy contains no specific clause excluding hability coverage for his intentional acts. See Allstate Ins. Co. v. Malec, 104 N.J. 1, 12, 514 A.2d 832, 838 (1986). Coinmentators have used an automobile insurance case, Nationwide Mutual Insurance Co. v. Roberts, 261 N.C. 285, 134 S.E.2d 654 (1964), to support the right to subrogation. See Note, supra note 15, at 1054 n.72. However, within the Roberts opinion, the court carefully distinguished between compulsory automobile insurance and other "voluntary" insurance. Roberts, 261 N.C. at 290-91, 134 S.E.2d at 659 . The court awarded the insurer the right to subrogation based on a specific section of the compulsory automobile insurance legislation, and consequently whatever subrogation is allowed appears limited to analogous situations. Id. at 293, 134 S.E.2d at 661.

269. Ruvolo v. American Casualty Co., 39 N.J. 490, 496-98, 189 A.2d 204, $207-09$ (1963).

270. Congregation of Rodef Sholom v. American Motorists Ins. Co., 91 Cal. App. 3d 690, 154 Cal. Rptr. 348 (1979).

271. Globe Am. Casualty Co. v. Lyons, 131 Ariz. 337, 641 P.2d 251 (Ct. App. 1981).

272. George v. Stone, 260 So. 2d 259, 262 (Fla. Dist. Ct. App. 1972).

273. Nationwide Mut. Fire Ins. Co. v. Turner, 29 Ohio App. 3d 73, 503 N.E.2d 212 (1986).

274. Arkwright-Boston Mfrs. Mut. Ins. Co. v. Dunkel, 363 So. 2d 190 (Fla. Dist. Ct. App. 1978).

275. Aetna Casualty \& Sur. Co. v. Dicht1, 78 Ill. App. 3d 970, 398 N.E.2d 582 (1980).

276. Mangus v. Western Casualty \& Sur. Co., 41 Colo. App. 217, 585 P.2d 304 (1978).

277. Northland Ins. Co. v. Mautino, 433 So. $2 \mathrm{~d} 1225$ (Fla. Dist. Ct. App. 1983), appeal denied, 447 So. $2 d 887$ (Fla. 1984).

278. See supra text accompanying notes 181-83.

279. See supra text accompanying notes 125-29.

280. For a discussion of the New Hampshire and Durham tests under criminal law, see supra text accompanying notes $126-29$. 
provide no guidelines for their insanity tests transfer the standard-making power to psychiatrists and are therefore susceptible to the resultant problems. One can argue that essentially undefined rules coinport well with the procoverage public policies behind insurance law, by giving a court more latitude to find an insured insane and thus preserve coverage despite an exclusionary clause. However, under such "non-rules," it seeins equally likely that the trial will become a battle of opposing experts, leaving the jury or judge essentially without guidance as to what beliavior is to be regarded as legally insane and thus beyond the scope of an intentional act exclusionary clause. Such a rule is ad hoc; it is difficult to apply consistently across varying facts. One commentator has pointed out that "[t]he law cannot simply adopt a concept developed by psychiatrists for therapeutic purposes .... [N]o other discipline's conceptualization can safely be adopted and plugged into a legal formula."281 The American Psychiatric Association itself has warned that the clinical and scientific considerations behind its diagnostic manual "may not be relevant to considerations in which [the inanual] is used outside chirical or research settings, e.g., in legal determinations."282

Specific mental and behavioral criteria are both well-estabhished and have received wide acceptance in insurance hitigation where the insured's mental capacity is in question. ${ }^{283}$ The criteria should be retained and explicitly put forth in order to provide guidelines to the court in its factfinding function. Such criteria provide a scope broad enough to protect the public interest in compensating the victim, while at the same time narrow enough to avoid confusion and inconsistency caused by an absence of all criteria.

\section{Problems of Ambiguity in Drafting the Criteria}

Tests including specific criteria for determining legal insanity in this context are not immune from criticism. The unclear separation of the cognitive and volitional prongs in Ruvolo has already been discussed, ${ }^{284}$ as lave the difficulties with the use of "derangement of the intellect" in Ruvolo and related cases. ${ }^{285}$ In addition, several other formulations of an insurance-focused insanity test suffer from ambiguities and unclear language in the drafting of their criteria that reduce their effectiveness.

The test developed in Congregation of Rodef Sholom v. American Motorists Insurance $\mathrm{Co}^{286}$ is a prime example of an anibiguous test.

281. M. MOORE, supra note 77, at 227.

282. AMERICAN PSYCHIATRIC Ass'N, supra note 256, at xxvi.

283. See supra text accompanying notes $132-82$ (discussing the Ruvolo line of cases applying both cognitive and volitional criteria).

284. See supra text accompanying note 150 .

285. See supra text accompanying notes $235-68$.

286. 91 Cal. App. 3d 690, 154 Cal. Rptr. 348 (1979). 
While it avoids using the term "derangement of the intellect" for the better "mental disease or defect," 287 and more clearly separates the cognitive and volitional criteria than does $R$ uvolo, ${ }^{288}$ the test employs circular logic within the cognitive element. As stated, the cognitive prong declares that if an insured suffered from a mental disease or defect that "deprived him of capacity to intend to [commit a wrongful act] and cause the damage complained of," 289 then the insured did not act intentionally. The problem here is that intention is what the test is supposed to determine. Instead of defining this "capacity to intend" as, for instance, an inability to understand the nature and consequences of an act or its moral wrongfuhiess, the Rodef Sholom test begs the question by using the word "intend" within its criterion. In effect, its criterion provides httle or no guidance to a court atteinpting to determine if an insured is sufficiently cognitively impaired to escape the operation of an exclusionary clause.

In addition, the Rodef Sholom court stated that the M'Naghten and A.L.I. criminal insarity tests were inadequate to serve the policies behind insurance law, which demand a broad interpretation of insanity, even though the A.L.I. test "inore nearly coinports to the proper rule." 290 It is ironic, therefore, that the Rodef Sholom test may be inore restrictive than the A.L.I. standard. The two tests share basically the same structure, since they both include cognitive and volitional prongs. However, the Rodef Sholom test as written seems to posit a complete deprivation of cognitive or volitional capacity, ${ }^{291}$ whereas the A.L.I test only demands a lack of substantial capacity. ${ }^{292}$ If, as the opimion states, the public's interest in the conipensation of victims demands that exclusionary clauses be interpreted as narrowly as possible, ${ }^{293}$ it is counterproductive to include language limiting the pool of insureds who might qualify under the standard to an even narrower pool than a criminal test.

Rosa v. Liberty Mutual Insurance Co. ${ }^{294}$ also provides an excellent exainple of unclear drafting. Unlike Rodef Sholom, the cognitive and vohtional elements, although present, are not clearly separated into distinct criteria. Instead, the langnage of the test combines both elements indiscriminately. As the court states, the insured's mental condition

287. Id. at 697,154 Cal. Rptr. at 352.

288. See supra text accompanying note 180 .

289. Rodef Sholom, 91 Cal. App. 3d at 697, 154 Cal. Rptr. at 352 (emphasis added).

290. Id., 154 Cal. Rptr. at 352

291. In its test, the court stated, "If [the insured] was suffering from a mental disease or defect which deprived him of capacity to intend ... or which deprived him of the capacity to govern his couduct in accordance with reason, then he did not act intentionally ...." Id., 154 Cal. Rptr. at 352 (emphasis added).

292. For a discussion of the A.L.I. standard, see supra text accompanying notes 107-13.

293. See Rodef Sholom, 91 Cal. App. 3d at 697, 154 Cal. Rptr. at 352.

294. 243 F. Supp. 407 (D. Conn. 1965). 
"deprived him of the ability to govern his conduct in accordance with reason and intent, to judge the nature, character and consequence of his act and to resist the impulses to do other than what he did."295 The first volitional prong, like that in Ruvolo, ${ }^{296}$ contains what can be seen as cognitive elements in the phrase "accordance witl reason and intent." However, the Rosa test's addition of the word "intent" to the Ruvolo "accordance witl reason" language is circular and adds nothing to the meaning of the criterion. Rosa expands upon Ruvolo's cognitive element with the phrase "nature, character and consequence," which adds a clearer sense of judicial standards. But the Rosa test then combines the cognitive element with the second volitional "resistance to impulse" element by using the conjunctive "and" instead of "or." Unlike the test in Rodef Sholom, which uses an "or" disjunctive between the cognitive and volitional elements, the Rosa test is not clearly broken into alternative prongs which would declare an act unintentional under either. Instead, under Rosa, it appears that both elements must be present. Whether or not such a result was intended, an insured who suffered from only one of the two conditions wonld probably be excluded under the Rosa test.

In order to comport with the public policies favoring a broader definition of insanity in insurance cases, a test must provide distinct, alternative cognitive and volitional prongs. In addition, a test must require that the insured lack only substantial capacity, not all capacity. Lastly, a workable test must avoid using the word "intent" within its language in order to refrain from circular logic.

\section{The "Minimal Cognitive Awareness" Tests}

The cases following Wagner use only a single cognitive awareness criterion: that of understanding the nature and consequences of one's act. ${ }^{297}$ As a result, they do provide a certain clarity and simplicity in the determination of an insured's imsanity. However, by usimg only one of the two $M$ 'Naghten prongs, they are extremely underinclusive, retaining coverage for only a very sinall percentage of people considered mentally ill. ${ }^{298}$ For exanple, the act of an insured who suffers from an overwhelming delusion that murder is acceptable or even demanded of him would not reflect sufficient impairment for the act to qualify as not intentional; ${ }^{299}$ nor wonld the acts of a cognitively coinpetent imsured who was unable to restrain his actions due to uncontrollable coinpulsions be

295. Id. at 409.

296. See supra text accompanying note $\mathbf{1 5 0}$.

297. For a discussion of the Wagner lime of cases, which consider only the cognitive prong of the M'Naghten test in making findings of insanity, see supra text accompanying notes 184-234.

298. See supra text accompanying notes $\mathbf{8 7 - 8 8}$ (noting that it is rare that a person will suffer from complete cognitive delusions).

299. See, eg., Johnson v. Insurance Co. of N. Am., 232 Va. 340, 350 S.E.2d 616 (1986) (insured 
without intent. Essentially, an insured who retains only a minimal level of cognitive awareness is declared able to form an intention, and is precluded froin insurance coverage for his deluded or coinpelled acts.

That position is not only rejected by all the criminal standards ${ }^{300}$ but is also in direct conflict with public policies arguing for a broader view of insanity for the purposes of insurance hitigation. Instead of supporting the doctrine that exclusionary clauses should be strictly construed against the insurer in order to reinforce the public interest in the compensation of victims, such a standard does the opposite: it gives an exclusionary clause sweeping powers to cover acts by insureds who in virtually any other context wonld be declared insane. Such a result is indefensible in insurance litigation, and shonld be rejected in favor of the inclusion of a cognitive criterion that encompasses the understanding of an act's inoral wrongfulness, and a volitional criterion that would encoinpass coinpelled acts.

\section{IV}

\section{A Proposal for a New Standard of INSANITy For USE IN INSURANCE CASES}

The interpretation of a hability pohicy's intentional act exclusionary clause when the insured nay be insane presents a vexing problein for courts attempting to balance the competing public policies governing msurance law. This Comment has atteinpted to show that the various tests courts traditionally apply in this situation suffer froin flaws that either daniage their clarity and effectiveness across different cases, or result in an overbroad or an overnarrow scope. To avoid these problems, and to strike the delicate balance between the policies emphasizing the deterrence of wrongful conduct and the policies demanding a narrow construction of exclusionary clauses, this Comment proposes a new standard. Acts would be deeined unintentional if

the insured suffered froin a mental disease, defect, or other involuntarily caused mental impairment which substantially deprived the person of the ability to understand the nature and consequences or inoral wrongfulness of the act, or which substantially deprived the person of the ability to control his conduct despite his understanding of the act or its wrongfulness.

This proposed standard uses familiar terminology froin existing tests under the rationale that "the task of reform is hikely to be easier if reli-

believed God had commanded him to kill the victim, but nevertheless vas found to have acted intentionally).

300. Even M'Naghten, the narrowest of all the criminal standards, contains a provision that would excuse an individual if he could not understand the moral wrongfulness of his acts. See supra text accompanying note 91 . 
ance can be placed upon doctrines of respectable lineage and relatively wide acceptance."301

Though the proposed standard presents no dramatic break from concepts and terminology used in existing tests, it contains several improvements over thein. First, it avoids the inclusion of harmful acts resulting from voluntary drug or alcohol intoxication, through the requirement of a "mental disease or defect or other imvoluntarily caused inental impairment."302 Involuntary mtoxications, such as an unexpected reaction to drugs taken pursuant to medical advice, would be included under this standard. In this respect, the proposed test balances the public policy deterring insureds from committing harmful acts by denying them coverage, and the policies recognizing a strong interest in the compensation of victims.

Second, the test contains and specifically delineates alternative cognitive and volitional criteria to avoid leaving courts without guidelines to judge an insured's legal insanity, ${ }^{303}$ and to ensure a sufficiently broad scope of application. ${ }^{304}$ Under the cognitive prong, the test retains the two M'Naghten elements-its criteria include those insureds who are actively hallucinatory and believe they are performing an entirely different act, as well as those who do not understand the wrongfulness of their acts. Laid out in this way, there can be no confusion as to whether the test includes a cognitive elenient, as there is in the $R u v o l o$ test. $^{305}$ The proposed test also contains a criterion focused as directly as possible on the insured's volitional capacity. As stated, this criterion removes any confusion from the cognitive prong, by substituting the phrase "despite his understanding of the act or its wrongfulness" for such phrases as "in accordance witlı reason."306 Finally, the proposed test demands only a lack of substantial capacity on the part of imsureds to satisfy each criterion, instead of requiring the total deprivation of capacity as suggested by other tests. ${ }^{307}$ Thus, the pool of insane insureds whose acts would avoid the operation of an exclusionary clause will not be madvertently narrowed to parameters even nore limited than tliose of the widely used A.L.I. criminal standard; the standard thereby adequately addresses the policy demanding the narrow interpretation of exclusionary clauses so that the public's interest in the compensation of victims is satisfied.

301. A. Goldstein, supra note 90, at 79.

302. For a discussion of the "disease" concept of alcoholism and other addictions, see supra note 240.

303. Cf. supra text accompanying notes $273-82$.

304. See supra text accompanying note 283.

305. For a discussion of the cognitive criteria laid out in the Ruvolo test, see supra text accompanying note 150 .

306. See id.

307. See supra text accompanying notes 290-93. 
The proposed test may not address all the difficulties endemic to a determination of whether a hability pohicy exclusionary clause bars coverage for an insane insured's acts. However, this test attempts to provide a inore detailed and workable concept of insamity that takes into account the pohicies and doctrines involved in this area of insurance law, thus leading to more consistent and fair judgments in cases where the mental capacity of an insured is in question. 